\title{
BİR NAKŞî SÛFÎ: MURTAZÂ EFENDİ VE VAKIFLARI
}

\author{
Nuran ÇETIN*
}

\section{Öz}

Medeniyet tarihimizde yüz yıllarca varllğııı sürdüren vakıf müessesesinin dînî, sosyal, kültürel yönden önemli izler bıraktığı görülmektedir. Devlet yöneticileri ve halk tarafından toplumun maddî ve mânevî ihtiyaçlarını karşılamaya yönelik olarak câmi, tekke, mektep, medrese, şifahâne gibi yapılar inşâ edilmiştir. Bu kuruluşlar, bünyelerinde oluşturulan muhtelif vakıflar vâsıtasıyla toplumun sağlık, sosyal, ibâdet ve eğitim gibi hizmetlerini icrâ etmişlerdir. Bu bahsedilen kuruluşların muhâfazası, tamirâtı, düzeni ve mâlî bakımdan desteklenmesi yazılı ve uygulamalı boyutu ile oluşturulan vakıf müessesesi ile olmuştur.

Bu makale iki bölümden oluşmaktadır. Birinci bölümde Murtazâ Efendi'nin hayatı ve tasavvufî yönü ele alınmıştır. İkinci bölümde ise söz konusu vakfiyenin muhtevâsı, Murtazâ Efendi'nin, eşinin ve kızının vakfettiği mülkler, vâkıfın şartları, vakfın giderleri ve vakfın idaresi konuları incelenmiştir. Son olarak ekler kısmında ise, vakfiyenin latinize edilmiş hâli verilmiştir.

Anahtar Kelimeler: Vâkıf, vakfiye, vakıf hizmetleri, Osmanlı, tekke

\section{A Nakhsi Sufi: Murtaza Lord and Foundations}

\section{Abstract}

It is seen that the institue of waqf, which has existed about centurys in our story of civillization, has important religious, social and cultural tracks. Goverments and people have made a lot of buildings like mosque, medresseh, hospital and school in order to get necessities including spritual and physical things. This institues have done serves about health, social, worship and education for society by means of different waqfs, which have been constituted from them. The protection, repair, order and supporting about money of mentioned institues have been provided by instution of waqf

The article is made up from two parts in the first part: The life of Mr. Murtaza and his style of Islamic mysticism is taken up. In the second part: The content of waqf's that is previously mentioned. Properties which his wife and daughter have dedicated, expense of waqf, condition of waqf and management of waqf are has been researched. At least in the part of attachments, the contidition of

* Yrd. Doç. Dr., Amasya Üniversitesi İlâhiyat Fakültesi, nuran.cetin@amasya.edu.tr 
70 | Nuran ÇETIN

waqf which is westerned has been given.

Keywords: Waqf, waqfiya, foundation services, Ottoman, lodge

\section{Giriş}

Allah'ın rızasını kazanabilmek amacıyla mâlî imkânı olan kişiler tarafından kurulan ve geliri ihtiyaç sahiplerine tahsis edilen kurumlardan biri olan vakıflar, ${ }^{1}$ yardımlaşma ve dayanışmanın sağlanmasında toplumun önemli bir mihenk taşı olmuştur. İnsan, sosyal yönü olan bir varlık olması hasebiyle, yardımlaşma ve dayanışmanın ilk insanla birlikte başladığını söyleyebiliriz. Fakat vakfın müessese olarak gelişmesi, hukûkî yönden statü kazanması ve ileri noktalara taşınması İslâmiyet ile birlikte gerçekleşmiştir. Vakıf kurumunun teorik yönden gelişmesinde ve toplumda kabul görüp yaygınlaşmasında, Müslümanların büyük katkılarının olduğu bilinen bir gerçektir. Bundan dolayıdır ki vakıf kurumu, adetâ İslâm kültürünün ayrılmaz bir parçası olarak kabul edilmiştir.

Vakıf, İslâm'ı kendisine referans edinen, ulvî duygu ve düşüncelere sahip insanların pratik hayata aktardıkları bir üründür. Bu anlamda vakıf, insanın fıtratında var olan yardımlaşma, dayanışma ve feragât gibi hususların sosyal hayata aktarılmış biçimidir. Tarihsel süreç içinde toplumda her kesimden insan, bu uygulamalara destek vermiş, adetâ iyilikte ve hayırda yarışma duygusu içinde pek çok vakıf kurumunun oluşmasına öncülük etmiştir.

Vakıf kurumlarında yaşanan en önemli gelişme, Selçuklular ve Osmanlılar devrinde olmuştur. Devlet yöneticileri ve halk tarafından câmi, mescid, tekke, zâviye, mektep, medrese, şifahâne, namazgâh, kütüphâne, imarethâne, dükkân, han, bedesten, çarşı, hamam, çeşme, sebil, kale, yol, köprü, kervansaray gibi muhtelif hizmet alanlarına yönelik binlerce vakıf kuruluşları tesis edilmiştir. ${ }^{2}$

İslâm kültür ve medeniyetinin daha iyi anlaşılabilmesi ve orijinal hâliyle gelecek nesillere aktarılabilmesi için, günümüze intikâl eden dînî, kültürel, sosyal, iktisâdî içeriğe hâiz olan vakfiyelerin iyi tetkik edilebilmesi gerekir. Bu anlamda Osmanlı dönemi toplumunun gündelik

1 Ziya Kazıcı, Osmanlı Vakıf Medeniyeti, Bilge Yay., İstanbul, 2003, s. 34.

2 Vakıf eserleri ile ilgili detaylı bilgi için bkz., Kazıcı, Osmanlı Vakıf Medeniyeti, s. 151246. 
hayatına sirâyet eden vakıf müessesesini, vakfiyeler ışığında ele almak, bu konuda atılabilecek en önemli adımdır. Bu amaca yönelik olarak tanıtımına esas aldığımız Murtazâ Efendi'ye ait vakfiye, geçmişten günümüze hayâtiyetini koruyan müstesnâ belgelerden biridir. ${ }^{3}$

XVIII. yüzyılda İstanbul ve Anadolu'nun çeşitli yerlerinde mülkler vakfeden, Osmanlı Devleti'nde kalemiyye sınıfında görev yapan Murtazâ Efendi'nin vakfettiği eserler, vakıf bünyesinde yer alan görevliler, bunlara ödenen meblağ, vâkıf tarafından uyulması istenen şartlar, vakfın idaresi gibi konular, bu makalenin ana temasını oluşturmaktadır. Söz konusu vakfiyeye geçmeden önce vakfedeni kısaca tanımanın yararlı olacağı düşüncesindeyiz.

\section{Murtazâ Efendi'nin Hayatı}

Makalenin bu bölümünde vakfiyeden ve klasik kaynaklardan edindiğimiz bilgiler çerçevesinde, Murtazâ Efendi'nin Osmanlı Dönemi'nde devlet adamı olarak icrâ ettiği görevlerine ve tasavvufî yönüne öncelikle yer vermek istiyoruz. Sicill-i Osmân $\hat{\imath}^{4}$ ve Sefine-i Evliyâa gibi kaynaklarda, Murtazâ Efendi'nin memuriyet hayatına yer verilmiştir. Vakfiyedeki bilgilerden öğrendiğimiz kadarıyla Murtazâ Efendi, devletteki vazifesinin yanı sıra, birçok hayır kurumunun kurulmasında katkıları olan önemli bir şahsiyettir. Bu hayır işlerine kızı ve hanımı olmak üzere yakın çevresi de iştirâk etmiş, böylece birlikte güçlü bir vakıf müessesesi oluşturmuşlardır. Âilece arkalarında güzel, kalıcı eserler bırakarak insanlığa örnek teşkil etmişlerdir. ${ }^{6}$

Murtazâ Efendi'nin Osmanlı Devleti'nde tersâne-i âmire emîni ve cizye muhasebecisi olarak görev yaptı̆̆ını, İstanbul'da Mahmutpaşa'da Veli Câmii yakınında ikâmet ettiğini, babasının adının Mehmed olduğunu bizim için birinci elden kaynak olan vakfiyeden öğrenmiş bulunuyoruz. ${ }^{7} \mathrm{Bu}$ anlamda Murtazâ Efendi ilmiyeden yetişmiş, daha çok muhasebecilik gibi hesap işleri alanında yüksek görevlere getirilmiştir. Murtazâ Efendi'nin maddî imkânlarının ne düzeyde olduğunu

3 İstanbul Müftülüğü Meşihat Arşivi, el-Hâc Murtazâ Efendi Vakfiyesi, nr., 1702.

4 Mehmed Süreyyâ, Sicill-i Osmanî, Matbaa-i Âmire, İstanbul, 1308, c. IV, s. 361.

5 Hüseyin Vassâf, Sefine-i Evliyâ-yı Ebrâr Şerh-i Esmâr-ı Esrâr, Süleymaniye Kütüphanesi, Yazma Bağışlar, nr. 2306, c. II, s. 46.

6 Murtazâ Efendi'nin, eşinin ve kızının vakfettiği mülkler, vakfiye metnine bağlı kalınarak ele alınacaktır.

7 Vakfiye, vr. 6a- 6b, 26b-27a. 


\section{I Nuran ÇETIN}

bilmiyoruz. Fakat onun tersâne-i âmire emîni olarak görev yaptığını kaynaklardan öğreniyoruz. Osmanlı Devleti'nde böyle bir vazifede bulunan kişinin maaşı oldukça yüksek düzeyde idi. Tersâne veznesinden çıkan paranın yüzde onu tersâne emînine maaş olarak ödenmekteydi. ${ }^{8}$ Muhtemelen Murtazâ Efendi, bu yüksek maaş imkânlarına sahip olması ile birçok hayır kurumunun kurulmasına katkıda bulunmuştur.

Murtazâ Efendi, 1146/1733 yılında tophâne nâzırı, 1147/1734 yılında tersâne emîni ${ }^{9}$ olarak vazife yapmıştır. Fakat bu görevine devam ederken, kısa bir süre sonra azledilmiştir. Bu durum çok fazla uzun sürmemiş 1151/1738 y1lında ikinci kere tersâne emîni olmuştur. 1153/1740 yllında Anadolu muhasebecisi, 1154/1741 yılında tekrar üçüncü kere tersâne emîni olmuş; fakat aynı yıl bu görevinden tekrar azledilmiştir. Elimizdeki bilgiler sınırlı olduğu için, onun hangi sebepten dolayı görevinden uzaklaştırıldığını tespit edemedik. Mühim bir sebepten olmasa gerek ki bu azlin akabinden kısa bir süre sonra tekrar görevinin başına dönmüştür. 1158/1745 yılında cizye muhasebecisi, 1159/1746 yılında rûznâme-i evvel olarak görevine devam etmiştir. ${ }^{10} \mathrm{Bu}$ görevlerinin dışında Murtazâ Efendi, bir süre vekâleten kaptan ${ }^{11}$ olarak da vazifede bulunmuştur. ${ }^{12}$

8 M. Zeki Pakalın, Osmanlı Tarih Deyimleri ve Terimleri Sözlü̈̆̈̈, İstanbul, 1993, c. III, s. 466.

9 Tersâne emîni; tersânenin ve diğer bütün harp gemilerinin gelir-gider defterleriyle inşaat, tamirât, alım-satım gibi işlerine bakan, depoları ve malzemeyi kontrol eden, tersâne hazînesinden sorumlu olan kişidir. Tersâne emîni, birinci sınıf hâcegân rütbesinde olup, dîvân müzâkerelerine iştirâk etmese de orada bulunarak, gerektiğinde sorulan sorulara cevap verirdi. Mithat Sertoğlu, Osmanlı Tarih Lügatı, Enderun Kitabevi, İstanbul, 1986, s. 333; Tersâne eminliği 1246/1830 yılında kaldırılmıştır. Bundan sonra bu vazife, Kaptan paşaların sorumluluğuna verilmiş ve bu iş için kendisine bir de yardımcı tâyin olunmuştur. Pakalın, Osmanlı Tarih Deyimleri ve Terimleri Sözlüğü, c. III, s. 466.

10 Süreyyâ, Sicill-i Osmanî, c. IV, s. 361.

11 Murtazâ Efendi'nin mesleği tersâne emîni idi. Bu vazifede bulunan kişi, kaptan paşa işi gereği denize çıktığında, ona vekâlet ederdi. Pakalın, Osmanlı Tarih Deyimleri ve Terimleri Sözlüğ̈̈̈, c. III, s. 465.

12 Şem'dânî-Zâde Fındıklılı Süleyman Efendi, Müri'it-Tevârih, c. I, (nşr. Münir Aktepe), İstanbul Üniversitesi Edebiyat Fakültesi, İstanbul, 1976, s. 111. 


\section{A. Murtazâ Efendi'nin Tasavvufî Yönü}

Murtazâ Efendi, hesap işleri alanındaki uzmanlığının yanı sıra tasavvufla da yakından ilgilenmiştir. Murtazâ Efendi'nin hayat çizgisi, hacca gittiği esnada Nakşibendî tarîkatının önde gelen isimlerinden Ahmed Yekdest Cüryânî (ö.1119/1707)'yi tanımasından sonra değişmiş ve ardından mezkûr şeyhe intisâb etmiștir. ${ }^{13}$ "Müceddid-i elf-i sânî" (ikinci bin yılın yenileyicisi) lakabıyla anılan İmâm-ı Rabbânî Ahmed Fârûk Sirhindî (ö.1034/1624)'nin öncülük ettiği Müceddidîliğe intisâb eden Murtazâ Efendi, onun oğlu Hâce Muhammed Mâsûm (ö.1079/1668)'un müridi Ahmed Yekdest Cüryânî'nin halîfelerinden biridir. ${ }^{14} \mathrm{Bu}$ anlamda Murtazâ Efendi'nin tasavvuftaki silsilesi Ahmed Yekdest Cüryânî (ö.1119/1707), Hâce Muhammed Mâsûm (ö.1079/1668) ve Ahmed Fârûk Sirhindî (ö.1034/1624) vâsitasıyla Nakşibendîliğin Müceddidiyye koluna dayanmaktadır. Murtazâ Efendi, söz konusu tarîkata sadece gönül vermekle kalmamış, vakfettiği Eyüp'teki tekkeyi de Nakşibendiyye tarîkatı müntesiplerine tahsis etmiştir.

Hayatı hakkında kaynaklarda kapsamlı bilgiye ulaşamadığımız Murtazâ Efendi, 1160/1747 yılında Ramazan ayının on altıncı günü vefat etmiştir. ${ }^{15}$ Eyüp'te, İdris Köşkü civârında vakfettiği kendi adıyla anılan tekkenin hazîresine defnedilmiştir. ${ }^{16}$ Âilesinin kabirleri de aynı yerde bulunmaktadır. Mezkûr tekkenin Haliç'e bakan ana kapısından girince, sağ tarafta parmaklık içinde ortalarda yer alan, yeşil renkli mermer taştan müteşekkil, sülüs ile yazılı kitâbede şu ifadeler yer almaktadır: "Hüve'r-Rezzâku'l-Bâkî/Sâhibu'l-hayrât/ ve'l-Hasenât sâbıkān/ Ruznamçe-i evvel merhûm/el-Hâc Murtazâ Efendil rûhuna el-fatiha, 1160/1747".

\section{Murtazâ Efendi'ye Ait Vakfiyenin Muhtevâsı}

Vakfın genellikle vâkıfı tarafından hazırlanmış nizamnâmesine (yönetmelik) vakfiye denilmektedir. ${ }^{17}$ Bilindiği üzere vakıflar, vakfı tesis eden kişinin belirlediği şartlara göre yönetilmekteydi. Vakfın yönetiminden ise mütevelliler sorumluydu. Bu anlamda vakfın tesisi, işleyişi ile ilgili hüküm, şart ve kâideleri içeren vakfiye, hukûkî bir belge niteliği taşımaktaydı. Sadece kadı tarafından tescil edilen vakfiyeler

13 Süreyyâ, Sicill-i Osmanî, c. IV, s. 361.

14 Sefine-i Evliyâ, c. II, s. 46.

15 Süreyyâ, Sicill-i Osmanî, c. IV, s. 361.

16 Vassâf, Sefinne-i Evliyâ, c. II, s. 46.

17 Kazıcı, Osmanlı Vakıf Medeniyeti, s. 49. 


\section{4 | Nuran ÇETİN}

kayda geçirilmekteydi. ${ }^{18}$ Vakfiyelerde genelde, Allah'a hamd-u senâ, vakfın ecir ve sevâbıyla ilgili âyet ve hadisler, vakf olunan mallar, vakfedilen malların nasıl idâre edileceği, vâridâtın yeri, sınırları, vakfın devamlılığı, vakfın ihtiyaç sahiplerine tahsisi, vakfın kimler tarafından yönetileceği, hâkimin vakfın sıhhat ve lüzûmuyla ilgili hükmü gibi hususlar yer almaktaydı. ${ }^{19}$

Tanitımına esas aldığımız vakfiyede, Allah'a hamd, Hz. Peygamber'e salât ve selâm ile başladıktan sonra, sadaka-i câriye'nin ve hayır-hasenât yapmanın önemine işaret eden ifadelere yer verilmiştir. Vakfın kurucusu hakkında kısa bir bilgi verildikten sonra, vakfın mâli yönü ile ilgili gelir getiren akârât ve hudutları belirleyen kısma değinilmiştir. Ayrıca vakfiyede, hizmet personelinin tayini, tesbiti, ücreti, görevlerinin neler olduğu ve yapılan harcamalar üzerinde durulmuştur.

İstanbul Müftülüğü Meşihat Arşivi'nde yer alan vakfiye, 1702 numarada kayıtlı olup, 105 varaktan ibarettir. Söz konusu vakfiyede Murtazâ Efendi'nin, eşi Behrî Hâtûn ile Kızı Selime Hanım'ın vakiyesi de yer almaktadır. Vakfiye metni Memmed Emin Efendi, Mehmed Sâlih elKâdı, Seyyid Mustafa İbn Mevlâ, Abdullah Mâhir el-Mevlâ, Yemliha Hasan el-Mevlâ adlı şahıslar tarafından kaydedilmiştir.

Türkçe, eski harflerle yazılan vakfiye dört bölümden müteşekkildir. İlk bölümü Murtazâ Efendi (ö.1160/1747)'nin vefatından bir yıl öncesine ait olup, 1159/1746 tarihlidir. İkinci bölüm 1161/1748 tarihli olup, bu bölümde Murtazâ Efendi'nin vakfettiği mülkler yer almaktadır. Üçüncü kısımda, Murtazâ Efendi'nin kızı Selime Hanım’ın 1175/1761 tarihli vakfiyesi bulunmaktadır. Son bölüm ise, Murtazâ Efendi'nin eşi Behrî Hâtûn'a ait olup, 1179/1765 tarihlidir. Vakfiyeden anlaşıldığ1 üzere Behrî Hâtûn ve Selime Hanım vakıflarının, Murtazâ Efendi'nin vakfına dâhil edilmesini istemişlerdir.

\section{A. Vakfedilen Mülkler (Müessese, Emlak, Arazi)}

Genel itibâriyle vakfiye metinlerinde, vakfedilen mülklerin neleri içerdiği ayrıntılı bir şekilde ele alınmaktadır. Söz konusu vakfiye örneğimizde de Murtazâ Efendi'nin mescid, câmi, tekke, mekteb, birçok ev, bahçe, su kuyuları vs. vakfettiği görülmektedir. Vâkıf Murtazâ Efendi, yaptığı hayr hasenâtın karşılığında Allah'ın rızasını kazanmayı,

18 Kazıc1, Osmanlı Vakıf Medeniyeti, s. 53.

19 Ali Himmet Berki, Vakfa Dair Yazılan Eserlerde Vakfiye ve Benzeri Vesikalarda Geçen Istılah ve Tâbirler, VGM Yay., Ankara, ty., s. 57. 
Bir Nakşî Sûfî: Murtazâ Efendi ve Vakıfları | 75

vefâtından sonra da hayırla yâd edilmeyi arzu etmiştir. Vakfettiği mülkler göz önünde bulundurulduğunda, onun çok yönlü vakıf düşüncesine sahip olduğu anlaşılmaktadır.

\section{a) Murtazâ Efendi'nin Vakfettiği Mülkler}

Vakfiye metninde yer alan ifadelere göre, Murtazâ Efendi'nin gelir getiren mülklerle birlikte on bin kuruş vakfettiği görülmektedir. Mezkûr zât, belirtilen bu meblağ ile uygun yerlerde mülkler satın alınmasını, kiraya verilmesini şart koşmuştur. ${ }^{20}$ Murtazâ Efendi, tekke, mescid, câmi gibi ibâdet mekânları dışında gayr-i menkûl olarak çok sayıda ev vakfetmiştir. Vakfedilen evlerde genelde altlı üstlü odalar, sofa, kiler, mutfak, hamâm, helâ, su kuyusu, ahır, avlu, ambar, ocak, mahzen, bahçe, köşk, odunluk, hol, geniş salon, mağsel, meyveli meyvesiz ağaçlar, su kuyuları gibi unsurlar bulunmaktadır.

Vakfiyede yer alan bilgiler ışığında, Murtazâ Efendi'nin vakfettiği mülkleri tablo hâlinde topluca ele almanın faydalı olacağ 1 kanaatindeyiz.

Murtazâ Efendi'nin Vakfettiği Mülkler

\begin{tabular}{|lr|lr|}
\hline Mülkler & aded & Mülkler & aded \\
\hline Mescid & 1 & Ticarethâne & 1 \\
\hline Câmi & 1 & Hallaç dükkânı & 1 \\
\hline Tekke & 1 & Manav dükkânı & 1 \\
\hline Mekteb & 1 & Yalı & 1 \\
\hline Ev & 237 odalı 55 ev & Bahçe & 23 \\
\hline Nakit & 10.000 kuruş & Bi'r-imâ & 49 \\
\hline Hamam & 2 & Kayık limanı & 1 \\
\hline Büyük oda & 6 & Mâilezîz(tatlısugelirleri) & 2 \\
\hline Odunluk & 1 & Balıçç mahzenleri & 4 \\
\hline Gümrükhâne & 1 & Kanevât (su kanalları) & \\
\hline Bakkaldükkânı & 1 & Meyveli meyvesiz ağaçlar & \\
\hline Dükkân & 1 & Külhan (Hamam Ocağı) & \\
\hline Berber dükkânı & 1 & 480 akçe mukataası olan bahçe &
\end{tabular}

b) Murtazâ Efendi'nin Kızı Selime Hanım'ın Vakfettği Mülkler İncelediğimiz vakfiye metninde sadece Murtazâ Efendi'nin değil; eşinin ve kızının İstanbul ve Anadolu'nun muhtelif yerlerinde vakıfları

$20 \quad$ Vakfiye, vr. 11b, 12a.

Amasya Üniversitesi İlahiyat Fakültesi Dergisi (Sayı 3) 
76 | Nuran ÇETIN

yer almaktadır. Vakfiyeden anlaşıldığı üzere Murtazâ Efendi'nin kızı Selime Hanım, vakfettiği 2.150 kuruş ile uygun yerlerde akâr satın alınmasını istemiştir. Vakfiye kaydında yer alan bu konudaki ifadeler şöyledir: "... Selime Hanım hayâtında ben bi-emrillâhi te'âlâ vefât eylediğimde vakf olmak üzre sülüs mâlımdan iki bin yüz elli kuruş ifrâz ve meblă̆-ı merkûme ile münâsib mahallerde akār iştirâ...". ${ }^{21}$

Vakfiyedeki bilgiler doğrultusunda Murtazâ Efendi'nin kızı Selime Hanım'ın vakfettiği mülklerin şu unsurlardan oluştuğu görülmektedir.

Murtazâ Efendi'nin Kızı Selime Hanım'ın Vakfettği Mülkler

\begin{tabular}{|lr|lr|}
\hline Mülkler & aded & Mülkler & aded \\
\hline Ev & 17 odalı 7 ev & Bi'r-imâ-sarnıç & 2 \\
\hline Nakit & 2.150 kuruş & Dükkân & 4 \\
\hline
\end{tabular}

\section{c) Murtazâ Efendi'nin Eşi Behrî Hâtûn'un Vakfettği Mülkler}

Murtazâ Efendi'nin kızı Selime Hanım gibi eşi Behrî Hâtûn da 6.000 kuruş vakfetmiştir. Bu belirtilen mablağ ile ile uygun görülen yerlerde akār satın alınmasını talep etmiştir. Ayrıca kendisine ait vakfın eşi Murtazâ Efendi'nin vakfına dâhil edilmesini istemiştir. Buna dâir vakfiye kaydında yer alan ifadeler ise şöyledir: "Nakşibendiyye Hânkâhı kurbunda arsa-i memlûkem üzerine mukaddemâ li-vechillâhi te'âlâ etfâl-i müslimîn içün binâ ve ihyâ eylediğim mekteb-i şerif ile atyeb mâl ve ahsen meâlimden ifrâz eylediğim altı bin kuruşumu hasbeten lillâhi te'âlâ vakf-ı sahîh-i müebbed ve habs-i sarîh-i muhalled ile vakf ve habs ve zevcim merhûm-ı mûmâileyh Murtazâ Efendi'nin hânkâh-ı merkûme vakfına zam ve ilhâk ve şöyle şart eyledim ki meblağ-ı mezkûr ile münâsib mahallerde akâr iştirâ ve icâreteyn-i misliyyeteyn ile îcâr...".22

Vakfiyede yer alan bilgilere göre, Murtazâ Efendi'nin eşi Behrî Hâtûn'un vakfettği mülkler özetle şu şekildedir:

Murtazâ Efendi'nin Eşi Behrî Hâtûn'un Vakfettği Mülkler

\begin{tabular}{|lr|lr|}
\hline Mülkler & aded & Mülkler & aded \\
\hline Ev & 69 odalı 20 ev & Bi'r-imâ & 14 \\
\hline Nakit & 6.000 kuruş & Bahçe & 14 \\
\hline Odunluk-Kömürlük & 7 & Mâilezîz & 1 \\
\hline Mektep & 1 & Sukuyusu & 1 \\
\hline
\end{tabular}

21 Vakfiye, vr. 73a.

22 Vakfiye, vr. 73a.

Amasya Üniversitesi İlahiyat Fakültesi Dergisi (Sayı 3) 


\section{B. Vakfiyede Belirtilen Giderler}

\section{a) Murtazâ Efendi Vakfı'ndan Yapılacak Harcamalar}

İbâdet ve eğitim gibi toplumsal hizmetlerin yerine getirilebilmesi amacıyla vakıf gelirlerinin câmi, mektep, tekke gibi kuruluşlara tahsis edilmesine yönelik ifadelere vakfiye metininde yer verilmiştir. Bunun dışında söz konusu bu mekânların o günkü koşullarda aydınlatılabilmesi için mum ve zeytinyağı, temizliği için gerekli personel, tamirâtı için yapılan harcamalar, misafirlere ikrâm için helvâ yapılıp dağıtılması gibi muhtelif masraflar, vakfiye örneğimizde detaylı bir şekilde ele alınmıştır. Anlaşıldığı üzere Murtazâ Efendi sadece câmi, mescid ve mekteb gibi mülkleri vakfetmekle kalmamış, bu mekânların işlevselliğini arttırmaya ve devamını sağlamaya yönelik olarak yapılması gerekenleri vakfiyede tek tek belirlemiştir. Vakfiyede yer alan bilgiler ışığında Murtazâ Efendi'nin vakfından yapılan harcama listesi, şu kalemlerden oluşmaktadır.

\section{Murtazâ Efendi Vakfı'ndan Yapılacak Harcamalar}

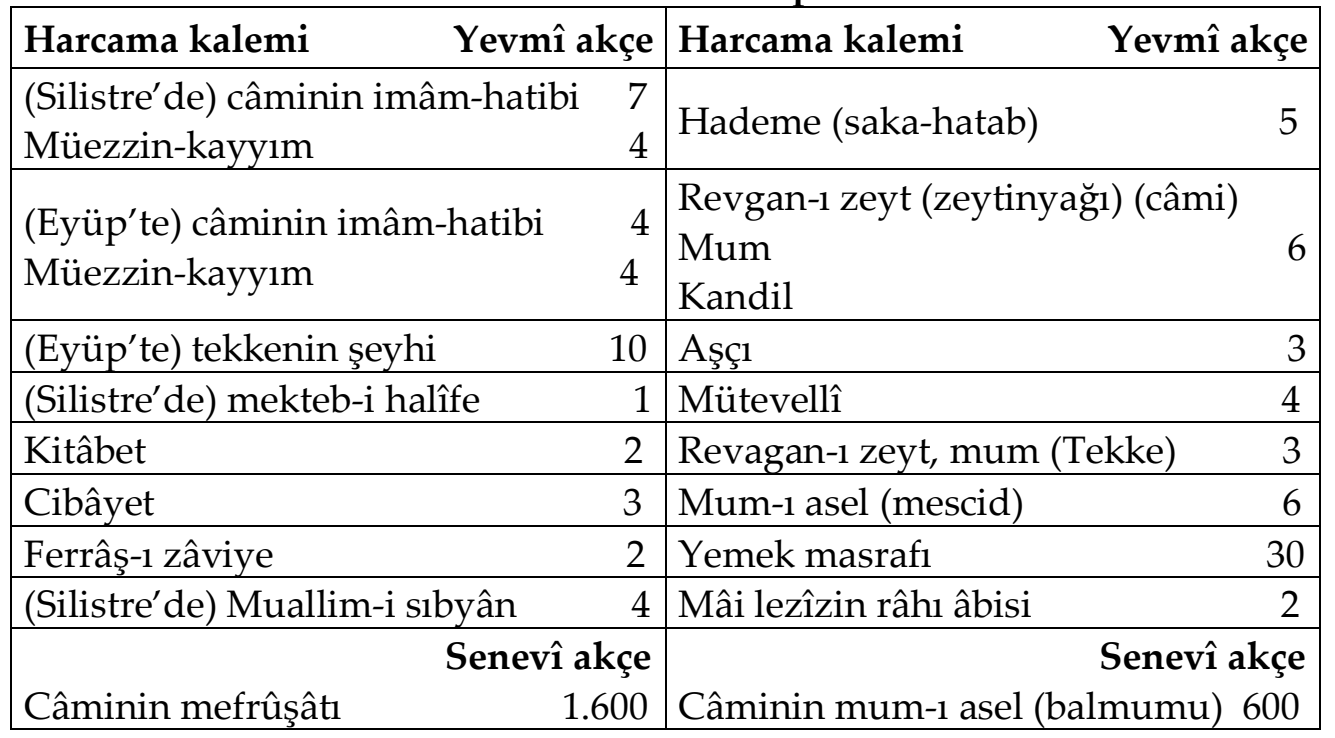

\section{b) Murtazâ Efendi'nin Kızı Selime Hanım'ın Vakfından Yapilacak Harcamalar}

Murtazâ Efendi'nin kızı Selime Hanım'a ait vakfiye metninin bulunduğu bölümde, fazla bir harcama kalemi zikredilmemiştir. Metinde yer alan ifadelere göre Selime Hanım, İstanbul Mahmud 
78 | Nuran ÇETİN

Paşa'da Veli Câmii'nde vâiz olarak tayin edilen kimseye yevmî 10 akçe verilmesini talep etmiştir. Bu konuda vakfiyede yer alan ifadeler şöyledir: "İstanbul'da Mahmudpaşa-yı Velî Câmi'-i şerîfinde cemâ'at-i müslimîne va'z u nasîhat içün ulemâdan bir kimesne vấ'z ta'yîn olunup yevmî on akçe vazîfe verile" 23

\section{c) MurtazâEfendi'nin Eşi Behrî Hâtûn'un Vakfından Yapılacak Harcamalar}

Daha önce de zikredildiği üzere, Selime Hanım ve Behrî Hâtûn kendilerine ait vakıfların, Murtazâ Efendi'nin vakfına dâhil edilmesini istemişlerdir. ${ }^{24} \mathrm{Bu}$ anlamda Behrî Hâtûn, eşi Murtazâ Efendi'nin vakfına kâtib ve câbî olarak görevlendirilen kimselerin kendi vakfına da kâtib ve câbî olmalarını talep etmiştir. Vakfiye kaydında buna dair yer alan ifadeler şöyledir: "zevcim mûmâ-ileyh Murtazâ Efendi'nin evkāfina kātib ve câbî olan kimesneler benim vakfıma dahî kātib ve câbî olup her birine yevmî bir akçe kitâbet ve cibâyet vazîfesi verile." 25

Osmanlı toplumunda hayırda öncülük eden hanımlardan biri olan Behrî Hâtûn, eşi Murtazâ Efendi'nin vakfettiği dergâhta ayda bir kere pazartesi geceleri Nakşibendiyye usûlü hatm-i hacegân zikri yapılmasını istemiştir. Zikir merâsimi sonrasında, gelen misafirlere ve tekkenin dervişlerine helvâ dağıtılmasını talep etmiştir. Helvâ dağıtımıyla ilgili malzemeler için de günlük 16 akçe ayrılmasını uygun görmüştür. Helvâ yenildikten sonra kendisine, eşi Murtazâ Efendi'ye, oğlu Halil Reşid Efendi'ye üç ihlâs bir fâtiha okunmasını, kendisi ve âilesi için dua edilmesini talep etmiştir. Vakfiye kaydında belirtilen bu husûsa dâir ifadeler şöyledir: "....ve sâlifü'z-zikr hânkāhda ayda bir kere leyle-i isneynde hatm-i hâcegân olup, akabinde tabh-ı helvâ için yevmî on altı akçe verilip tenâvel olunduktan sonra kemâl-i keremlerinden bu fakîre ve zevcim mûmâ-ileyhin ve sadrî oğlum müteveffâ Halil Reşî̀ Efendi için üçer ihlâs-l şerîfe ve birer fâtiha-i şerîfe okunup sevâbını rûhumuza ihdâ ve hayr duâ buyuralar..."26

Bilindiği üzere vakfedilen tekkeler özelde belli bir tarîkatın dervişlerine tahsis edilmiş olsa da genel itibâriyle bu mekânlar tüm mü'minlerin ibadet alanıdır. Bu anlamda Behrî Hâtûn, eşinin vakfettiği tekke ve câmide Kur'ân okunması için, Kur'ân-1 Kerîm ve bunun

23 Vakfiye, vr. 64a.

24 Vakfiye, vr. 72a.

25 Vakfiye, vr. 74a.

26 Vakfiye, vr. 73a-b 
yanında otuz adet Kur'ân cüzlerinin olduğu bir sandık vakfetmiştir. Kur'ân tilâveti noktasında ehil olan iki kişinin Kur'ân-ı Kerîm okumasını, ardından yapılan duâda sevâbını kendi rûhuna, eşi Murtazâ Efendi ve oğlu Halil Reşîd Efendi'nin rûhlarına ve ayrıca Hz. Peygamber'in, sahâbenin diğer tüm mü'minîn ve mü'minâtın rûhlarına hediye edilmesini talep etmiştir. Kur'ân-1 Kerim'i okuyana günlük iki akçe ve cüzleri okuyan kişiye iki akçe olmak üzere toplam dört akçe verilmesini şart koşmuştur. İlgili vakfiye kaydında buna dâir yer alan ifadeler şunlardır: "..tekye-i merkûmede câmi şerîfde ve vakfı sahîh ile ve vakf ve sandik ile vaz' eylediğim bir kıt'a-i Kelâm- kadîm-i şerîf ve otuz aded iczâa-i kelâm-ı kadîm-i şerîfi iki kimse tilâvet ve sevâbını benim ve zevcim mûmâ ileyhin ve oğlum mûmâ ileyh Halil Reşî̀d Efendi'nin ve sâir cemî̀ mü'minîn ve mü'minâtın rûhlarna ihdâ ve mukâbelesinede mushaf-ı şerîfi tilâvet eden kimseye yeumî iki akçe ve eczâ-i şerîfeyi tilâvet eden kimseye dahî yeumî iki akçe vazîfe verile...". ${ }^{27}$

Vakfiyede yer alan bilgiler doğrultusunda özetle ifade edecek olursak, Murtazâ Efendi'nin eşi Behrî Hâtûn'un vakfından yapılacak harcama listesi şu kalemlerden oluşmaktadır.

\section{MurtazâEfendi'nin Eşi Behrî Hâtûn'un Vakfından Yapılacak Harcamalar}

\begin{tabular}{|lr|lr|}
\hline Harcama kalemi & Yevmî akçe & Harcama kalemi & Yevmî akçe \\
\hline Muallim-isıbyân & 5 & Câbî & 1 \\
\hline Mekteb-ihalîfe & 2 & Kur'ân-1 Kerim'i okuyan kişi & 2 \\
\hline Kâtib & 1 & Kur'ân cüzü okuyan kişi & 2 \\
\hline Mütevellî & 1 & Tabh-1 helvâ & 16 \\
\hline
\end{tabular}

\section{Vâkfın Şartları}

Murtazâ Efendi'nin hayatını ele aldığımız kısımda onun, Nakşibendiyye tarîkatına intisâb ettiğini ifade etmiştik. Bu anlamda Murtazâ Efendi, Eyüp'te vakfettiği tekkeyi, müntesibi olduğu tarîkatın dervişlerine tahsis etmiştir. Vakfiye kaydında, söz konusu tekkede bulunan odaların kimler tarafından kullanılacağı ayrıntılı olarak zikredilmiştir. Buna göre tekkede, toplam beş oda yer almaktadır. Murtazâ Efendi, bir odanın şeyh efendiye diğer dört odanın ise ise tekkenin dervişlerine tahsisini uygun görmüştür. Bu konuda vakfiyede

$27 \quad$ Vakfiye, vr. 73b, 74a. 
80 । Nuran ÇETİN

belirtilen ifadeler şöyledir: "Nakşibendiyye'den bir kimesne şeyh olup yevmî on akçe meşîhat vazîfesine mutasarrif olup, binâ olunan beş bâb odanın birinde sâkin ola...ve mâ-adâ dört bab odada Nakşibendiyye fukarâsı sâkîn ola...". ${ }^{28}$

Allah'ın rızasını kazanmak amaciyla kurulan vakıflarda ilmî, ahlâkî ve edebî her yönden üstün vasıflara sahip olan kişilerin görev alması gerektiği vakfiyelerde özellikle zikredilen husûslardan biridir. Murtazâ Efendi de tekkenin şeyhi vefât ettiğinde, yerine gelecek kişinin kâmil mânâda tarîkat ehli, okur-yazar, Hanefî mezhebine mensup, takvâsı tam bir kişi olmasını istemiştir. Ayrıca Nakşibendiyye tarîkatının ileri gelenlerinin uygun görmesi ve mütevellinin arz etmesi ile bu tayin işleminin gerçekleşmesini şart koşmuştur. Vakfiye kaydında bu husûsa dâir yer alan ifadeler şöyledir: “...şeyh olan kimesne fevt oldukta meşâyıh-ı Nakşibendiyye'nin münâsib gördükleri bir kâmil tarîk ve okur-yazar mezhebi Hanefìyye'den bir ehli takvâ kimesne mütevellî arzı ile şeyh ta'yîn oluna..." ${ }^{29}$ Aynı şekilde, imâm ve hatip olarak görevini îfâ eden kişilerin vefâtı akabinde bunların yerine gelecek kimselerin Kur'ân tilâvetine vâkıf, ilim ve amel bütünlügüune sahip kişiler arasından seçilmesi istenmiştir. $\mathrm{Bu}$ konuda ilgili vakfiye kaydında yer alan ifadeler şöyledir: “...Imâmet ve hitâbete ve hocalığa mutasarriflar fevt oldukta mücevvid ve tilâvete kādir ve şerâît-i İslâmiyyeye ârif müstahik ve muhtâr cemaât evlâdlart bulunur ise mütevellî arzı ile evlâdına tevcîh oluna. Müstahık olmayan evlâdına verilmeyip müstehik olan kimselere verile....". ${ }^{30}$

Vakfiye metninde yer alan ifadelere göre, İstanbul ve Anadolu'nun muhtelif yerlerinde çok sayıda ev, dükkân gibi gayr-i menkuller vakfedilmiştir. Bunlardan elde edilen kira gelirlerleri ile Murtazâ Efendi, vakfettiği câmi, mescid, mekteb ve tekkenin ihtiyaçlarının karşılanmasını şart koşmuştur. Vakfiyede "meşrûta" ibâresi kullanılmıştır ki bu da ilk sahibi tarafından ev, tarla, arsa gibi taşınmazların satılmamak şartıyla kendisinden sonra gelen mirasçılara bırakılması anlamına gelmektedir. ${ }^{31}$ Murtazâ Efendi, "evlâd-ı ve evlâd ve evlâd-ı ve evlâd ve evlâd-ı ve evlâdıma batnen ba'de batnin meşrûta ola" diyerek vakfettiği akârâtın kendisinden sonraki nesillere intikâlini arzu etmiştir. Öncelikle ilk kuşaktaki soyundan gelen kız ve erkek evlâdlarına, ardından ikinci kuşaktaki kız

28 Vakfiye, vr. 14a.

29 Vakfiye, vr. 14a.

30 Vakfiye, vr. 19b-20a

31 Ferit Devellioğlu, Osmanlıca-Türkçe Ansiklopedik Lugat, Aydın Yay., Ankara, 2012, s. 733. 
ve erkek evlâdlarına, sonrasında üçüncü kuşaktaki kız ve erkek çocuklarına, onların da nesli kalmadığında kardeşlerine intikâl etmesini istemiştir. Bunların da inkırâzında kardeşlerinin bir, iki ve üçüncü kuşaktaki kız ve erkek evlâdlarına intikâlini talep etmiştir. Kendisinin ve kardeşlerinin neslinden kimse kalmadığnda ise vakıf gelirlerinin Medine-i Münevvere'de bulunan fakir Müslümanlara gönderilmesini şart koşmuş̧tur. ${ }^{32}$ Bununla birlikte Murtazâ Efendi, vakfın gelirlerinden bir kısminin her sene Haremeyn-i Şerîfeyn'de bulunan fakirlere ulaştırılmasını da istemiştir. Bu husûsa dâir vakfiye kaydında yer alan ifadeler şöyledir: "...bâlâda tahrîr olunduğu üzere zevâyid-i merkûmeyi be-her sene Haremeyn-i Şerîfeyn fukârasina irsâl ve îsâl için Haremeyn-i Şerîfeyn mütevellîsine teslim oluna...".33

Vakfiye metninde zikredilen tüm bu şartlarda azaltma, çoğaltma ve değiştirme gibi husûsların söz konusu olmaycağı özellikle belirtilmiştir. Herhangi bir özür sebebiyle değişikliğin olması hâlinde ise vakfın, fakir Müslümanlara meşrûta olduğu ifade edilmiştir. ${ }^{34}$

\section{Vakfın Tevliyeti (İdaresi)}

Vakıf gelirlenin vakfedenin belirlediği şartlar doğrultusunda amacına uygun olarak kullanılıp kullanılmadığının kontrolünü sağlamak üzere mütevellî olarak bilinen idârî bir organizasyon teşekkül ettirilmiştir. Bu anlamda vakıf mütevellisi olarak görev üstlenen kimse, kendisine emanet edilen vakfa âit malları korumak ve onları idare etmekle yükümlüydü. Vakıf mütevellileri bu hizmetleri karşılığında belli bir ücret almaktayadı. Bunun meblağı da yine vakfedenler tarafından vakfiye metninde belirtilmiştir.

Vakfiye metninden anlaşıldığı üzere, Murtazâ Efendi yaşadığ 1 sürece vakfın tevliyetinin kendi üzerinde olmasını şart koşmuştur. Vefatından sonra ise bu görevin evlâdları tarafından icrâ edilmesini, sonrasında ise ikinci ve üçüncü kuşaktaki neslinden gelen kişilerin bu vazifeyi yürütmesini istemiştir. Murtazâ Efendi, vakfiyede yer alan "Batnen ba'de batnın" ifadesiyle böylece vakfın tevliyetinin nesilden nesile intikâlini arzu etmiştir. Bu üç kuşakta neslinden gelen kimse kalmaması durumunda ise mütevellîlik görevinin kardeşi Hacı Halil Ağa'ya,

32 Vakfiye, vr. 16a-b,17a.

33 Vakfiye, vr. 19b.

34 Vakfiye, vr. 20a-b, 21a. 


\section{I Nuran ÇETIN}

sonrasında kardeşi Hacı İbrahim Ağa'ya verilmesini şart koşmuştur. Kendi evlâtlarında olduğu gibi, aynı şekilde kardeşlerinin bir, iki ve üçüncü kuşaktaki evlâtlarının yaşça büyük olanlarına bu görevin verilmesini talep etmiştir. ${ }^{35}$ Murtazâ Efendi, bu belirtilenlerin dışında neslinden gelen kimse kalmaması hâlinde ise vakfın ileri gelenlerinin uygun gördügü güvenilir kişinin mütevellî olmasını şart koşmuştur. İlgili vakfiye kaydında yer alan ifadeler şöyledir: “...ba'de inkirâzî küll vakf-ı mezbûre nâzır muşâru'n-ileyh hazretleri re'yiyle bir mu'temed kimesne mütevellî olup...". ${ }^{36}$

Vakfiye örneğimizde yer alan Selime Hanım, babası Murtazâ Efendi'nin vakfına mütevellî olacak kişinin, kendi vakfına da mütevellî olmasını istemiştir. Bu konuda vakfiyede yer alan ifadeler şöyledir: "Vakf-ı mezbûr babamız merhûm Murtazâ Efendi'nin Medîne-i Eyüb'de İdris Köşkü kurbunda binâ ve ihyâ eylediği Nakşibendiyye Zâviyesi Vakfi'na her kim mütevellî olur ise ol kimesne benim vakfima dahî mütevellî ola ve vakf-ı merhûm babamı merhûmun vakfına zamm ve ilhâk oluna". ${ }^{37}$

Vakfiye metnimizin son bölümünde yer alan Murtazâ Efendi'nin eşi Behri Hâtûn, yaşadığı sürece vakfın tevliyetinin kendi üzerinde olmasını istemiştir. Vefatından sonra ise Giritli Hacı İbrahim Ağa'nın, onun da vefatından sonra oğlu Halil Reşid Efendi'nin kızı Hatice Hanım'ın mütevellî olmasını istemiştir. Hatice Hanım'ın vefâtından sonra ise onun neslinden gelen kız ve erkek çocukların en sâlih ve en reşid olanlarının yaşça en büyük olanına bu vazifenin verilmesini istemiştir. Tamamen neslinden kimse kalmadığında ise eşi Murtazâ Efendi'nin vakfına tevliyet eden kimsenin kendi vakfına da mütevellî olmasını şart koşmuştur. ${ }^{38}$

\section{Sonuç}

Osmanlı Devleti'nin toplumsal yapısında var olan yardımlaşma ve dayanışma uygulamalarının yakından anlaşılabilmesi için, o döneme ışık turtan vakfiye metinlerinin iyi tahlil edilebilmesi gerekir. Bilindiği üzere, Anadolu'da kültür ve medeniyetin gelişmesinde vakıfların büyük rolü olmuştur. Bu vakıf örneklerinden biri de XVIII. Yüzyılda İstanbul ve

35 Vakfiye, vr. $17 \mathrm{~b}-19 \mathrm{~b}$

36 Vakfiye, vr.19b.

37 Vakfiye, vr. 64b.

38 Vakfiye, 75a-b, 76a. 
Anadolu'nun muhtelif yerlerinde âilesi ile birlikte câmi, mescid, mekteb gibi mülkler vakfeden Murtazâ Efendi'ye aittir. Vakfiye metninde verilen bilgiler 1şığında Murtazâ Efendi ve âilesinin yaptıkları hayır hasenâtları, vakfettikleri mülkleri ele almış bulunmaktayız.

Vakfiye örneğimizde vâkıfın kimliği, nerede ikāmet ettiği, vakfettiği mülkler, vakıf gelirleri ve kullanım yerleri, vakıf bünyesinde görev alan personelin vasıfları, bunlara hizmetleri karşılığında ödenen meblağ, vakfın tevliyeti, (yönetimi), vakfın devamı gibi husûslar üzerinde ayrıntılı olarak durulmuştur. $\mathrm{Bu}$ anlamda tanıtımına esas aldığımız vakfiyede öne çıkan özellikler şöyledir: Murtazâ Efendi'nin Eyüp'te Nakşibendiyye müntesiplerine vakfettiği tekkede eşi Behrî Hâtûn, pazartesi akşamları, hatm-i hâcegân zikrinin icrâ edilmesini istemiştir. Zikir merâsimi bittikten sonra dervişlere ve gelen misafirlere helvâ dağıtılmasını talep etmiştir. Buna dâir masraflar için vakfın gelirlerinden belli bir miktar ayrılmasını istemiştir. Vakfiyede yer alan bu bilgiler 1şığında mezkûr tekkede helvâ dağıtma uygulaması olduğunu anlıyoruz. Behrî Hâtûn ayrıca, tekkeye ve yanında bulunan câmiye Kur'ân-1 Kerîm ile Kur'ân cüzlerinin olduğu bir sandık vakfetmiştir. Kur'ân Kerîm okuyan görevliler için de belli bir meblağ verilmesini şart koşmuştur. Vakfiye örneğimizde de görüldüğü üzere câmi, mekteb ve tekke gibi kuruluşlar vakfedenler, sadece bu müesseseleri tesis etmekle yetinmemişler; buralarda icrâ edilen faaliyetlerin devamını sağlamaya yönelik olarak harcama kalemlerini tespit edip, vakıf kayıtlarında buna yer vermişlerdir. Ayrıca bu kuruluşlarda görev üstlenenlerin kâmil mânâda tarîkat ehli, Kur'ân tilâvetine vâkıf, ilim ve amel bakımından öncü şahsiyetler olması gerektiği de vakfiye örneğimizde üzerinde durulan husûslardan biridir. Vakfedilen müesseselerde, belirtilen özelliklere sahip nitelikli, vasıflı şeyh, imâm ve muallimlerin Osmanlı Dönemi sosyal yapısında dinî, ilmî, kültürel ve ahlâkî yönden büyük izlenimler biraktı̆̆ bilinen bir gerçektir.

Bütün bunlarla beraber zikredilen şartlarda değiştirme, arttırma ve azaltma gibi husûsların olamaması gerektiği de vakfiyede öne çıkan özelliklerden biridir. Eğer geçerli bir özür sebebiyle şartlarda herhangi bir değişime gidilmesi durumunda vakfın ihtiyaç sahibi fakir Müslümanlara tahsis edilmesi gerektiği vakfiyede ifade edilmiştir.

Sonuç olarak, Osmanlı Dönemi'nde şehir merkezlerinden en ücrâ noktalara kadar câmi, mescid, mekteb ve tekke gibi çok sayıda kuruluşlar binâ edilmiştir. Tarihî süreç îtibâriyle bu müesseselerin pek 
84 I Nuran ÇETIN

çoğu yangın, deprem gibi muhtelif nedenlerle ya tamamen ortadan kalkmış, ya da yapılan onarımlarla fizikî olarak değişime uğramıştır. Hiç olmazsa günümüzde mevcûdiyetini koruyan eşsiz hazine niteliğindeki kültürel değerlerimizi vakfiye içeriklerinden tanıyarak, vâkıfların şartları doğrultusunda bunlara sahip çıkmamız toplum olarak öncelikli vazifelerimizden biri olmalıdır.

\section{EK 1}

\section{Vakfiyenin Transkript Edilen Metni ${ }^{39}$}

[1a] Taalluku bimâ fîhi satrü'l-fakîr ileyhi sübhânehû ve te'âlâ ketebehû el-fakîr Mehmed Emîn -ufiye anhü-

Mâ-fî hâzihi'r-rakme mine'l-vakf ve's-sebîl câmi'un bimâ tesihhü bihi'l-evkāf bi't-teslîm ve't-tescîl haysü [...] münâsebe şurûten ve kuyûden ve uhkimet me'ânîhi rusûmen ve hudûden. Harrarahû el-fakîr el-müstemea'h min-fazl-i Rabbihi'l-kadîr azze şânuhû Mehmed Sâlih elKādî bi-dâri's-saltanat-i Kostantınıyye el-mahmiyye -gufira lehû-

[...] fî hâzihi'l-evrâki'l- mebsure ve'r rusûm fî [...] es-sahâifi'lmestûra mine'l-vakf ve'ş-şurût ve ta'ayyün el-masârıf ale'l-munammati'lmebsût cerâ ledeyye ve vaka'a beyne yedey ve innî hakemtü bi's-sıhhati ve'l-lüzûmi vâkıfen bi'l-ihtilâf fî emri'l-evkāf beyne'l-e'immeti'l-eşrâf. Harrarahû el-abdü'l-fakîr ileyhi sübhânehû Es-Seyyid Mustafa ibni'lMevlâ Abdullah Mâhir El- Mevlâ hilâfetehû bi-mahkemet Mahmudpaşa bi-medînet Kostantınıyye -gufira lehümâ-

[1b] Bismillahirrahmanirrahim

Envâ'-1 hamd-ı cemîl vesnâf-1 şükr-i cezîl ol vâkıfü ahvâl ve ef'al ve mukaddirü erzâk ve âcâl olan vâcibü'l-vücûd ve mümteni'ü'l-misâl cânibine mahsûr ve ol vâhibü hâh ve celâl olan fâizü'l- [2a] cûd ve müttes'ü'n-nevâl dergâhına maksûrdur ki cümle mevcûdâtı kudret-i kâmilesiyle ibdâ' ve âmme-i masnû'âtı hikmet-i şâmilesiyle ihtirâ' edip husûsen hilkat-i Âdem'i ketm-i ademden vücûda getirip sâhibü akl-i selîm ve mekteb-i tekvînde cümle eşyâ ve esmâyı tallîm kılıp zümre-i insânı "velekad kerremnâ benî âdeme" ihsânıla mükerrem ve mümtâz [2b] ve merâtib-i sâmiye-i dünyeviyye ve uhreviyyede tefâvüt-i kadr ve şân ve temâyüz-i sümüvv-i mekân ile "verafa' ba'zahüm fevka ba'din derecâtin" masdûk-1 kerîmi sûret-i zuhûrda ibrâz edip ba'zılarını servet

39 İstanbul Müftülüğü Meşihat Arşivi, el-Hâc Murtazâ Efendi Vakfiyesi, nr., 1702. 
ve yesâr i'tâsıyla tahsîl-i zâd-1 ahrete ikdâr ve mazhar-ı beşâret "men câe bi'l-haseneti felehû aşr emsâlihâ" olmakla miknet ve iktidâr ihsân etmekle tertîb-i [3a] hayrât-ı bâkiye ve techîz-i sadakāt-i câriyeye tevfîk ile ser firâz eyledi. Ve salâtün salavâtün mütevâliyâtün ve tahiyyâtün behiyyâtün mütedâliyât ol makbûl-i dergâh-1 ilâhi ve mahrem-i harem lî ma'allâh. Sultân-1 serîr bülend ve püstî şehriyâr-1 memâlik vücûd ve heştî âric-i me’âric-i "vema erselnâke" râkî-i merâtib-i "levlâke levlâke" müşerrefi kerîme-i "sübhânellezî esrâ" [3b] Habîb-i Hüdâ Rasûl-i Kibriyâ imâm-1 enbiyâ muktedâ-yı asfiyâ hâce-i muallimhâne-i âlem Muhammedini'l-Mustafa sallalâhü te'âlâ aleyhi vesellem bi-adedi men samt ve tekellüm hazretlerinin Ravza-i mutahhara ve türbe-i münevverelerine ihdâ ve îsâr olunur ki ümmete uli'l-himmetlerine tarîk-i mesûbât ve müberrâtı izhâr ve sebîl-i sadâkāti rağib ve ihbâr eyledi mekteb-i fazlına irse Mûsâ görecek [4a] olurdu ana asâ ve vürûd-ı şeref ve zûd-1 nâ-ma'dûd ervâh-1 pür fütûh-1 âl ve ashâb-1 bâhiretü'ssu'ûdlarına ittihâf olunur ki her biri sipihr-i hidâyetde necm tâbdâr ve evc-i vilâyetde birer kevkeb-i âlî-mikdâr rıdvânullâhi te'âlâ aleyhim ecma'în

Emmâ ba'd her sa'îd ve edîb ve her reşîd ve lebîbe lâyık ve hakîkatdir ki bu dünyâ-yı bî-karâr-1 [4b] nâ-pâyidârın fenâsını fenâ ile meşhûn ve ğınâsını 'gınâ ile makrûn idiğini çeşm-i ibret ile müşâhede ve ni'amî hatr ve zevâl ve mükîmi şeref-i irtihâlde olduğunu ayn-1 basîret ile mu'âyene edip kable hulûli'l-ecel "ve mâ emrunâ illâ vâhidetün kelemhin bi'l-basar" fehvâ-yı şerifîni teemmül ile mûcib-i kelâm-ı kadîm "Men leyse ma'bûd sivâhu" "Ve mâ tukaddimû li-enfüsiküm min hayrin tecidûhu indallâh" [5a] ve muktezâ-yı hadîs-i rasûlullâh sallalâhü aleyhi ba'de'l-emtâr ve'l-miyâh "izâ mâte ibn-i âdeme inkata'a amelühû illâ anselâsin. İlmün yüntefeu bihî ve veledün sâlihun yed'û lehû ve sadakatün câriyetün fî sebîlillâh" ile âmil ola binâen alâ zâlike fırsat-ı iktidâr-1 kâmurânî ve sermâye-i hayât-1 zindegânî elde iken iştirâ-yı ucûr ve mesûbât emrinde isti'câl etmeyenlerin [5b] tedârik-i zâd mi'âdı arza fuât ve nâm-1 nişânı kendü ile pâdâş-1 merk ve memât olduğu gibi iddihâr-1 mesûbât ve hasenât ve hayrât edenler "Yevme tüczâ küllü nefsin bimâ kesebet" mükâfât-hâsında vâsıl-1 ni'am bâkiye olduğu mahsûm-1 fuâd kaviyyü'l i'tikādları olmakla ibkā-yı meâsir ve mesâ'îye mecd ü sâ‘̂̂ ve hadîs-i şerîf "Leyse leke min dünyâke illâ mâ ekelte fefnit ev lebiste [6a] fe-ebleyte ev tasaddak fe-ebkayt" mazmûnuna mürâ'î olup işbû kitâb-1 meşkîn nikābın tahrîr ve imlâ ve tastîr-i inşâsına bâ'is ve bâdî oldur ki 


\section{6 | Nuran ÇETIN}

Devlet-i aliyye-i ebediyyü'l-istimrârda sâbıkān Tersâne-i âmire emîni ve Cizye muhâsebecisi olup mahmiye-i İstanbul'da Mahmudpaşa Mahallesi'nde sâkin umdetü ashâbi't-tasattur ve'l-kalem zübdetü erbâbi't-tahrîr ve'r-rakam sâhibü'l-hayrât [6b] ve'l-hasenât râğıbü'lmüberrâti'l-âliyât sa'âdetlû semâhatlû El-Hâc Murtazâ Efendi ibni'lmerhûm Muhammed meclis-i şer'-i şerîf-i Ahmedîyi ve mahfil-i münîf-i dîn-i Mustafavî'de zikri âtî vakfına li-ecli't-tescîl ve li-itmâmi't-tekmîl mütevellî nasb ve ta'yîn ettikleri Ahmed Ağa b. Mehmed mahzarında ikrâr-1 sahîh-i şerî̂ ve i'tirâf-1 sarîh-i mer'î eyleyip zikri câî vakfın sudûruna değin yedimde mülk ve hakkım [7a] olan Mahmiye-i İstanbul'da Voynuk Şüca' Mahallesi'nde vâki' bir tarafdan Osman Yazıcı Mülkü ve bir tarafdan Osman Ağa kerîmesi mülkü ve bir tarafdan İsmail Efendi veresesi mülkü ve bir tarafdan tarîk-i hâs ile mahdûd dâhileyyede fevkānî bir oda ve dehlîz ve hammâm ve mahzen ve vustâda bir oda ve bir kârgîr matbah ve hammâm ve kenîf ve dehlîz ve tahtânî [7b] bir mahzen ve bi'r-i mâ bahçe ve havlu ve kiler ve hâriciyyede fevkānî iki oda ve bir sofa ve vustâda iki oda ve dehlîz ve süflâda bahçe ve havluyu ve müştemilât-1 sâireyi hâvî mülk menzil ve yine mahmiye-i mezbûrede Balat Kapısı dâhilinde Hammâmcı Muhyiddin Mahallesi'nde vâki’ etrâf-1 erba'ası Kılıçcı Hasan ve Papas menzilleri ve Kılıçcı Kabrîl ve Döşemeci Duka menzilleri [8a] ve Nakkāş Yûsuf mülkü ve Kassâbbâşı ve Değirmenci Todori mülkleri ve tarîk-i âm ile mahdûd yirmi dokuz bâb oda ve müştemilât-1 ma'lûme-i sâireyi hâvî mülk Yahûdihâne ve yine mahrûsa-i Galata'ya tâbi' kasaba-i Kasımpaşa'da El-Hâc Ahmed Mahallesi'nde Handeresi demekle ma'rûf mevzi'de vâki' etrâf-1 erba'ası tarîk-i âm ile mahdûd fevkānî iki oda ve dehlîz ve tahtânî [8b] bir oda ve sekiz aded bi'r-i mâ ve eşcâr-1 müsmire ve gayr-1 müsmireyi ba'zan taş ve ba'zan kerpiç duvarlı bahçe ile lede'l-ahâlî ve'l-cîrân ma'lûmü'l-hudûd ve müştemilât-1 ma'lûmeyi hâvî ikisinin senede merhûm Sultan Bâyezîd Vakfı'na dört yüz seksen akçe mukâta'ası olan bahçelerimin eşcâr ve ebniye-i memlûkelerini ve yine mahrûsa-i mezbûreye muzâfe Ortaköy Nahiyesi'ne tâbi' Rumeli Hisarı [9a] kurbunda Kayalar nâm mevzi'de vâki' bir tarafından Çavuşzâde Efendi Yalısı ve bir tarafından ba'zan sâbıkān İstanbul Kādısı atûfetli Dürrîzâde Mustafa Efendi Hazretleri Yalısı bahçesi ve ba'zan Osman Ağa Bağı ve bir tarafdan Molla Mehmed Yalısı ve bir tarafından tarîk-i âm ile mahdûd hâriciyyede fevkānî üç bâb oda ve bir sofa ve dîvânhâne ve tahtânî bir oda ve bir matbah ve kayık limânı [9b] ve bi'r-mâ ve kenîf ve eşcâr-1 müsmire ve gayr-1 müsmireli 
bahçe ve dâhiliyesinde fevkānî dört oda ve bir sofa ve dehlîz ve tahtânî bir matbah ve bir mahzen ve hammâm ve câmekān ve kenîf ve bi'r-i mâ ve bir mikdâr bahçeyi müştemil ve önünde sayd-1 mâhî için mevzû' iki dalyânı hâvî yalı ta'bîr olunur mülk menzil ve yine mahrûsa-i mezbûreye muzâfe kasaba-i Tophâne'de Firûzağa Mahallesi'nde vâki'[10a] bir tarafından ba'zan Zarîfe Hâtûn ve bir tarafdan Ya'kûb Ağa ve bir tarafından Sarrâc Ahmed ve bir tarafından ba'zan Ali Ağa ve ba'zan Rastıkcı Sâliha ve ba'zan tarîk-i hâs ile mahdûd fevkānî iki bâb oda ve bir sofa ve iki tahtânî oda ve bi'r-i mâ ve bahçeyi müştemil mülk menzil ve yine Galata dâhilinde Sultan Bâyezid Mahallesi'nde vâki' bir tarafından da Âişe Hâtûn ve bir tarafdan Anastaş Zimmî [10b] mülkü ve bir tarafından Horasancı dükkânı ve bir tarafından tarîk-i âm ile mahdûd fevkānî bir oda ve sofa ve dehlîz ve tahtında kenîf ve havluyu müştemil mülk menzil ve Medîne-i Üsküdar'da Hasanağa Mahallesi'nde vâki' etrâf-1 erba'ası İsmail Ağa ve Süleyman Paşa Vakfı'ndan bahçe ve Es'ad Paşa Medresesi ve Mahmûd Efendi menzilleri ve tarîk-i hâs ile mahdûd tahtânî beş bâb oda ve iki sofa ve kenîf ve bi'r-i mâ [11a] ve bahçeyi müştemil mülk menzilimi ve yine vilâyet-i Anadolu'da Medîne-i Manisa'da vâki' etrâf-1 erba'ası tarîk-i âm ile mahdûd ve Tahte'l-kal'a Hammâmı dimekle ma'rûf ve külhan ve odunluk ve kanavâtıyla mâlik olduğum ma'lûmü'l-mikdâr mâ'-i lezîz cârîyi ve sâir müştemilâtı hâvî mülk çifte kebîr hamâmımı ve Medîne-i Hazret-i Ebî Eyyüb el-Ensârî radıyallâhü anhu Rabbihi'l-bârîde- Zeyneb Hâtûn Mahallesi'nde vâki'[11b] bir mescid-i şerîf ve beş bâb oda ve fukarâ ta'âm yemek içün bir kebîr oda ve kenîfleri ve Medîne-i Eyüb civârında Kara Hasan Ağa Karlığ kurbunda Kızllyarlar nâm mahalde müceddeden hafr olunan oniki aded âbârdan hâsıl ma'lûmü'l-mikdâr mâ-i lezîzî ve bir mikdâr bahçeyi müştemil iki kıt’a mülk arsam üzerinde mebnî zâviye-i latîfeyi ve etyab mâl ve ahsen menâlimden ifrâz eylediğim on bin [12a] kuruşumu hasbeten lillâhi's-Samed ve taleben li-merzâti Rabbihi'l-ehad vakf-1 sahîh-i mü'ebbed ve habs-i sarîh-i muhalled ile vakf ve şöyle şart eyledim ki meblağ-1 mezbûr on bin kuruş ile münâsib mahallerde akār iştirâ olunup iştirâ olunan akārât ile bâlâda tahrîr olunan akārât-1 icâreteyn ile âhara îcâr ve hâsıla olan icârâtdan vilâyet-i Rumeli'de Silistre kazâsi'na tâbi’ [12b] Baylar nâm karyede mukaddemâ li-vechillâhi te'âlâ binâ ve ihyâ eylediğim câmi'-i şerîfde bir kimesne imâm ve hatîb olup yevmî yedi akçe vazîfeye mutasarrıf ola ve bir kimesne dahî câmi'-i mezkûrda müezzin ve kayyım olup yevmî dört akçe vazîfeye mutasarrıf 
88 । Nuran ÇETIN

ola ve yine karye-i merkûmede li-vechillâhi te'âlâ binâ eylediğim mektebde câmi'-i merkûmda her kim imâm ve hatîb olur ise ol kimesne mu'allim-i sıbyân [13a] olup yevmî dört akçe vazîfeye mutasarrıf ola ve câmi'-i merkûmda müezzin olan kimesne dahî mekteb-i mezbûrda halîfe olup yevmî bir akçe vazîfeye mutasarrıf ola ve câmi'-i mezkûra ve mekteb-i merkûme kifâyet mikdârı su getiren sakāya ve eyyâm-ı şitâda mekteb-i mezbûra mikdâr-1 kifâyet hatab getiren bir kimesneye yevmî beş akçe vazîfe verile ve câmi'-i merkûmda îkād olunacak revgan-1 zeyt [13b] ve şem' ve kandil bahâ yevmî altı akçe verile ve yine câmi'-i merkûm mihrâbının yemîn ve yes'ârında îkād olunmak içün mûm-1 asel bahâsı olmak üzre beher sene altı yüz akçe verile ve câmi'-i mezkûrun ve mekteb-i mezbûrun mefrûşâtı içün senevî altı yüz akçe verile ve Medînei Eyüb el-Ensârî'de binâ ve ihyâ eylediğim zâviye-i latife-i Nakşibendiyye fukarâsına meşrûta ve meşâyih-i Nakşibendiyye'den [14a] bir kimesne şeyh olup yevmî on akçe meşîhat vazîfesine mutasarrıf olup binâ olunan beş bâb odanın birinde sâkin ola şeyh olan kimesne fevt oldukda meşâyih-i Nakşibendiyye'nin münâsib gördükleri bir kâmil tarîk ve okur yazar mezheb-i Hanefiyye'den bir ehl-i takvâ kimesne mütevellî arzı ile şeyh ta'yîn oluna ve mấadâ dört bâb odada Nakşibendiyye fukarâsı sâkin ola ve her kim [14b] zâviye-i merkûmede şeyh olur ise derûn-1 zâviyede li-vechillâhi te’âlâ binâ eylediğim mescid-i merkûmda imâm olub yevmî dört akçe imâmet vazîfesine mutasarrıf ola ve sükkân-1 zâviyeden biri dahî müezzin ve kayyım ve bevvâb olup yevmî dört akçe vazîfeye mutasarrıf ola ve biri dahî zâviye-i merkûmede tabbâh olup yevmî üç akçe verile biri dahî ferrâş-1 zâviye olup yevmî iki akçe [15a] vazîfeye mutasarrıf ola ve sükkân-1 zâviye içün ta'âmiyye olmak üzre yevmî otuz akçe verile ve câmi'-i merkûmda ve tekye-i merkûmenin çeşmesinde îkād olunmak içün yevmî üç akçe revgan-1 zeyt ve şem' bahâ verile ve mescid-i mezbûr mihrâbının yemîn ve yes'ârında îkād olunmak içün senede altı vakiyye mum-ı asel iştirâ olunup mescid-i mezbûrun mihrâbına vaz' oluna [15b] ve câmi'-i mezbûrun mefrûşâtı içün senede bin akçe verile ve karye-i mezbûrede vâki' câmi' ve mektebin ve Medîne-i Eyüb'de olan zâviye ve mescid-i şerîfin ta'mîrât ve termîmâtı iktizâ ettikde vakfın zevâyidinden ola vazîfe-i tevliyet yevmî dört akçe ve vazîfe-i kitâbet yevmî iki akçe ve vazîfe-i cibâyet yevmî üç akçe ola ve Medîne-i Eyüb'de olan zâviyeye cârî mâ-i lezîzin [16a] râh-1 âbîsine yevmî iki akçe vazîfe verile ve zevâyid-i vakf-1 mezbûrdan evvelâ sâlifü'z-zikr câmi' ve mescid-i şerif ve mekteb ve zâviye ve su yolunun 
ta'mîrât ve termîmâtı takdîm olunup mâ'adâ kalan zevâyid ibtidâ kendü nefsime meşrûta ola dâr-1 bekāya rihletimden sonra ta'mîrâtdan bâkî kalan zevâyîd-i vakf-1 mezbûr mutlaka evlâd-1 ve evlâd ve evlâd-1 ve evlâd ve evlâd-ı ve evlâdıma batnen ba'de batnin meşrûta ola [16b] hâsıl1 kelâm ba'de't-ta'mîrât zevâyid-i vakf her derecede evlâd-ı evlâd ve evlâdımın zükûr ve inâsı beynlerinde ale's-seviyye taksîm oluna evlâdım ınkırâzında karındaşlarım beyninde karındaşlarımdan sonra karındaşlarımın evlâd-ı evlad-ı evlâd zükûr ve inâsı beyninde batnen ba'de batnin ale's-seviyye taksîm oluna ba'dehüm utekā ve utekātımız beyninde ale's-seviyye taksîm oluna ba'dehüm evlâd-1 evlâd-1 evlâd-1 [17a] utekā ve atîkātımın zükûr ve inâsı beyninde ale's-seviyye taksîm oluna ba'de inkırāzi'l-küll zevâyid-i vakf-1 mezbûr Medîne-i Münevvere fukarâsına îsâl oluna ve vakf-1 merkûma Dârü's-sa'âdeti'ş-şerîfe Ağası hâfız-1 nâmûs-1 saltanat ve nâzıru evkāf-1 Harameyn-i şerifeyn âlîmenkıbet olan devletlü sa'âdetlü ağa efendilerimiz hazerâtı hasbî nâzır olup indallâhi te'âlâ me'cûr ve mesâb[17b] olalar ve tevliyet-i merkûme evvelen ben lâbis-i libâs-1 hayât oldukça bana dâr-1 fenâdan dâr-1 bekāya rıhlet eylediğimde evvelen sulbî evlâdımın zükûrunun ekberine el-iyâzü billâh te'âlâ batn-1 evvelde olan evlâd-1 zükûr ınkırâzında yine batn-1 evvelde olan evlâd-1 inâsın ekberine meşrûta ola batn-1 evvelde evlâd-1 zükûr ve inâs ınkırâzında batn-ı sânî ki elvâd-ı evlâdımdır anın zükûrunun ekberine batn-ı mezbûrda [18a] zükûr ınkırâzında yine batn1 sânîde olan evlâd-1 inâsımın ekberine meşrûta ola. Batn-1 sanîde olan evlâd-1 zükûr ve inâs inkırâzında batn-1 sâlis ki evlâd-1 evlâd-1 evlâdımdan anın zükûrunun ekberine bat-ı sâlisde olan evlâd-ı zükûr ınkırâzında yine batn-ı sâlisde olan evlâd-ı inâsımın ekberine vech-i meşrûh üzre tevliyet-i mezkûre evvelâ evlâd-ı zükûra sâniyen evlâd-ı inâsa batnen ba'de batnin ilâ inkırâzi'l-küll [18b] meşrûta ola ba'dehüm tevliyet-i merkûme karındaşım El-Hâc Halil Ağa'ya ba'dehu âhar karındaşım El-Hâc İbrahim Ağa'ya meştûrta ola. Karındaşlarımdan sonra benim evlâdım tasarrufu gibi karındaşlarım mezbûrânın evlâd-ı evlâd-ı evlâd-ı evlâdları ki her bir batında evvelâ zükûrun ekberine zükûr ınkırâzında batn-1 mezbûrda olan inâsın ekberine batnen ba'de batnin meşrûta ola. Batn-1 evvelde zükûr ve inâs ınkırâzında [19a] batn-1 sânîde olan evlâd-1 zükûrun ekberine ba' dehüm yine batn-1 sânide inâsın ekberine batn-1 sânîde zükûr ve inâs ınkırâzında batn-1 sâlisde olan evlâd-1 evlâd-1 evlâd-1 zükûrun ekberine zükûr ınkırâzında inâsın ekberine ilâ inkırâzi'l-küll meşrûta ola. ba'dehüm evvelâ utekāma 
90 । Nuran ÇETIN

ba'dehüm atîkātıma ba'dehünne utekā ve atîkātımın her batında evvelâ evlâd-ı zükûrlarının ekberine ba'dehüm evlâd-ı inâsın ekberine bâlâda tafsîl [19b] olunduğu gibi benim ve karındaşım evlâdı gibi evlâd-ı evlâd-1 evlâd-ı utekā ve atîkātıma batnen ba'de batnin meşrûta ba'de ınkırâzi'lküll vakf-ı mezbûre nâzır müşârun-ileyh hazretleri re'yiyle bir mu'temed kimesne mütevellî olup bâlâda tahrîr olunduğu üzre zevâyid-i merkûmeyi beher sene Harameyn-i şerîfeyn fukarâsına irsâl ve îsâl içün Harameyn-i şerîfeyn mütevellîsine teslîm oluna imâmet ve hitâbete ve hâceliğe [20a] mutasarırflar fevt oldukda mücevvid ve tilâvete kādir ve şerâyit-i İslâmiyeyi ârif müstehık ve muhtâr cemâ'at evlâdları bulunur ise mütevellî arzı ile evlâdına tevcîh oluna. müstehık olmayan evlâdına verilmeyip müstehıkk olan kimesnelere verile ve zikr olunan şurûtumun cümlesinin vüzerâ-yı izâm ve nâzır-1 vakf hazerâtı ve hukkâm-1 şer mer'î buyurup hilâfına cevâz göstermemeleri mercûdur [20b] ve şurût-1 muharrere-i mezkûrenin tebdîl ve tağyîr ve taklîl ve teksîri merraten ba'de uhrâ yedimde ola ve şurût-1 mezkûreye ri'âyet müte'azzire olunur ise vakf-1 mezbûr mutlakâ fukarâ-i müslimîne meşrût ola deyü tebyîn-i şurût ve ta'yîn-i kuyûd edip meblağ-1 merkûm onbin kuruş ile akārât-1 muharrere-i mezkûreyi her birini mahallerinde mütevelli-i merkûme fâriğan ani'ş-şevâğıl teslîm ol dahî her birini ahz u kabz ve emsâli [21a] gibi tasarruf eyledi dedikde gibbe't-tasdîki'ş-şer'i vâkıf-1 mûmâ-ileyh semt-i vifâkdan cânib-i şikāka âzım ve bi'z-zât husûmet ve nizâ'a câzım olup vakf-1 nukûd ve ana müteferri‘ olan şurût kuyûd-1 eimme-i selâse-i nehârîr aleyhim -rahmetullâhi'l-meliki'l-kadîr- mezheb-i hatîrlerinde bâtıl ve İmâm-1 Samedânî Hazret-i Muhammed b. Hasan Eş-Şeybâni re'y-i münîrlerinde vâkıf menfa'at-i vakfı nefsine [21b] şart eylese sihhatden âtıl olduğundan mâ'adâ arz-1 vakf üzerinde olan ebniye ve eşcâr hükm-i mankûlde olup ve menkûl ve muhavvel kısmının vakfiyyeti câiz ve sahîh olmadığı kütüb-i mu'teberede mastûr olmakla evkāf-1 mezbûreden benim içün bâb-1 rücû' meftûh olmağın zikr olunan nukûd-1 mezkûreyi ve eşcâr ve ebniyeyi istirdâd ederim dedikde mütevelli-i merkûm dahî cevâb-1 bâ-savâba mütesaddî[22a] olup eğerçi hâl minvâl-i muharrer üzeredir lakin İmâm-ı Züfer hazretlerinen İmâm Abdullah El-Ensârî rivâyeti üzre vakf-ı nukûda ve ana müteferri' olan şurût kuyûd sahîh ve câiz olup ve arz-1 vakf üzerinde olan bina ve eşcâr gerçi menkûl kabîlindendir lakin menkûl müte’ârifdir örf dahî umûm üzeredir ve İmâm-1 Rabbânî Muhammed b. Hasan Eş-Şeybânî hazretleri menkûl-i müte'ârifîn sıhhatine zâhib [22b] olduğundan gayrı bir cihet 
içün mevkûf arz üzerinde olan binâ ve eşcâr cihet-i uhrâya vakf olunsa ikisinin mutlakâ hayırda ittihâdına nazar edip ba'zı eimme-i kirâm ve fukahâ-i zevi'l-ihtirâm hazerâtı sıhhat ve cevâzına zâhiblerdir ve Hazret-i İmâm Ebû Yûsuf katında vâkıf mücerred vakaftü dimekle ve İmâm Muhammed Hazretleri re'y-i münîrlerinde teslîm ile'l-mütevellî olunmakla sahîh ve câizdir [23a] deyü redd ve teslîmden ebâ ve imtinâ' ve husûmet-i nizâ' edip hâkim-i muvakk1'-1 sadr-1 kitâb tûbâ lehû ve hüsn meâb efendi hazretleri huzûrunda müte'ârifân ve her biri fasl ve hamse tâlibân oldukda hâkim-i mûmâ-ileyh tarafeynin kelâmına nazar ve mennâ'in li'l-hayr olmadan hazer edip eimme-i izâm ve fukahâ-i zevi'l-ihtirâm aleyhim rahmetullâhi'l-meliki'l-allâm hazerâtından [23b] alâ kavl-i men yerâhu. Evkāf-ı mestûrenin sıhhatine hükm-i sahîh-i şer'î ve kazâ-i sarîh-i mer'î eyledikden sonra vâkıf-1 mûmâ-ileyh in'ân-1 kelâmını semt-i âhara atf edip sıhhat-i müstelzim lüzûm olmamakla benim içün yine bâb-1 rücû'meftûhdur deyü tekrâr istirdâd eylediklerinde mütevellî ârifü'l-mesâil dahî cevâbında fasl-1 müctehid fîhi hükm-i hâkim ve kaza-i kādi lâhık olmakla [24a] sıhhat-i vakfında ittifâk ve cevâz-1 habsde vifâk olup ve İmâm-1 A'zam ve Hümâm-1 akdem hazretleri katında sıhhat müstelzim lüzûm değil ise İmameyn-i Hümâmeyn mezheb-i hatîrlerinde sihhat-i vakfiyyet lüzûmunda müfârakat eylemesi anların kavl-i şerîfleri üzre dahî hükm ricâ ederim dedikde hâkim-i mûmâ-ileyh -Esbağallâhü ni'amehû aleyh- [24b] hazretleri dahî evkāf-1 mezbûrenin sâniyen İmâmeyn-i Hümâmeyn bedreyn-i muhteremeyn hazretlerinin kavl-i şerîfleri üzre lüzûmuna hükm ve kazâ ve hükm-i sâbıkını imzâ buyurub evkāf-ı mezbûre sahîh ve lâzım ve mütehattim olup nakz ve nakîzına mecâl adîmü'l-ihtimâl oldu."Fe-men beddelehû ba'de mâ semi'ahû fe-innemâ ismuhû ale'llezîne yübeddilûnehû. İnnallâhe semî'un alîm." [25a] Ve ecre'l-vâkıf ale'lhayyi'l-kerîm. Cerâ zâlike.

Ve hurrire fî evâhir-i Cumâdeti'l-ûlâ li-sene tis'a ve hamsîn ve mi'e ve elf min-hicretin men lehü'l-izzi ve'ş-şeref

Şuhûd:

El-Hâc Mustafa Efendi Kâtib-i evvel-i Mahkeme-i Mahmudpaşa, Feyzullah Efendi b. Hüseyin İmâm-1 Câmi'-i Mahmûdpaşa, Fahrü'lakrân Nesli zâde İsmail Ağa b. Mehmed es-sâkin bi-Mahmudpaşa, Sebzîzâde Şerif Ağa b. Ömer es-Sâkin bi-Mahmudpaşa, El-Hâc Ömer Ağa b. Yahyâ es-Sâkin bi-Mahmudpaşa, Hâfız El-Hâc Mustafa Efendi b. Ömer Efendi es-Sâkin bi-Muhmudpaşa, El-Hâc Abdülkadir Ağa b. 
92 | Nuran ÇETİN

Mahmûd es-sâkin bi-Mahmudpaşa, Nesli zâde es-Seyyid Ahmed Efendi Kâtib-i Dîvân, Sâlih Efendi b. Mahmûd vekîl-i İmâm-1 Mahmud Paşa, Attâr İbrahim Çelebi b. Halil es-Sâkin bi-Mahmudpaşa, Anbar Emîni Ahmed Ağa b. Mehmed, Sergi Emîni İsmail Ağa b. Mehmed, [25b] Konak Hocası Osman Efendi, Kapıçuhadârı El-Hâc Ali Ağa, Konak İmâmı Mustafa Efendi, Mühürdâr El-Hâc Yûsuf Ağa b. Abdurrahman, Mehmed Efendi b. Ali tâbi'-i Vâkıf, Hamcı Mehmed Çelebi b. Mustafa, Berber Mustafa b. Hamza, Molla Mustafa b. Mehmed, Esirci El-Hâc Ali b. Mustafa, Kaymakam Çırağı Çuhadâr Ali Bey tâbi'-i Vâkıf, Uzun Ahmed Bey tabi'-i Vâkıf, Bıyıklı Hasan Bey tâbi'-i Vâkıf, Üsküdârî Mustafa Bey tâbi'-i Vâkıf, Hanegî Çuhadâr Mustafa tâbi'-i Vâkıf, Bodur es-Seyyid Osman tâbi'-i Vâkıf, El-Hâc Ahmed Çuhadar Vâkıf, Kilârî El-Hâc Hasan tâbi'-i Vâkıf, Mühürcü Mehmed tâbi'-i Vâkıf, Mevlevî Halil Bey tâbi'-i Vâkıf, Es-seyyid Sâlih Çelebi tâbi'-i Vâkıf, Kuhel Mehmed Çelebi tâbi'-i Vâkıf, Hasan Çelebi tâbi'-i Vâkıf, Yörük Ali Bey tâbi'-i Vâkıf, Vekil-i harc Ahmed Ağa tâbi'-i Vâkıf, Çuhadar Mehmed tâbi'-i Vâkıf, Esirci Osman Paşa komşu, Aydınlı Mustafa tâbi'-i Nesli zâde, Esirci Süleyman b. Mustafa komşu, [26a] Mehmed Ağa b. Abdülbâkî, Ahmed b. Hasan, Kavukçubaşızâde Türbedâr Hâfız Mehmed Efendi, Eskici Mûsâ b. Hüseyin, Süleyman tâbi'-i başkâtib

[26b] Mâ fîhi mine'z-zam ve't-tescîl kad sâre lâzimen bi'l-hulm ve'ttesbîl ve innî kazaytü bi-sihhatihî ve lüzûmihî fî husûsihî ve umûmihî âlimen bi'l-hilâf beyne'l-eimmeti'l-eslâf ve'l-eşrâf fî emri'l-evkāf ve ene'lfakîr ilâ Rabbihi'l-kadir Nimetullah el-Müfettiş bi-evkāfil-Harameyni'lmuhteremeyn -gufira lehû-

Bismillahirrahmanirrahim

El-hamdü lillâhi Rabbi'l-âlemîn ve's-salâtü ve's-selâmü alâ seyyidinâ Muhammedin ve âlihî ve sahbihi ecma'în.

Emmâ ba'd işbû kitâb-1 sıhhat nisâbın tahrîr ve imlâ ve tastîr ve inşâsına bâ'is ve bâdi oldur ki Devlet-i Aliyye-i Osmâniyye'de sâbıkān Tersâne-i âmire [27a] emîni ve Ruznamçe-i evvel olan sâhibü'l-hayrât ve'l-hasenât merhûm ve mağfûrun leh El-Hâc Murtazâ Efendi b. Mehmed Ağa'nın hâl-i hayâtında vilâyet-i Rumeli'de Silistre Kazâsı'na tâbi' Baylar nâm karyede binâ eylediği câmi'-i şerîf ve mekteb-i münîf ve Medîne-i hazret-i Ebâ Eyyüb el-Ensârî -radiye anhü Rabbihi'l-bârîdebinâ eyledği zâviyenin levâzımı içün vakf ve tescîl eylediği evkāf-1 şerîfelerinin evlâdiyyet [27b] ve meşrûtiyyet üzre mütevellîsi olan vâkıf-1 mûmâ-ileyhin sulbî sâğîr oğlu Mehmed Sa'îd Efendi tarafından umûr-1 
vakfı rü'yete kāimmakām mütevellî olan umdetü'l-emâsil El-Hâc Ahmed Ağa b. El-Hâc Mehmed meclis-i şer'-i şerîf-i Ahmedî ve mahfil-i dîn-i münîf-i Muhammediyyede vakf-1 âti'z-zikri li-ecli't-tescîl ve'l-itmâm emri't-tekmîl mütevellî nasb olunan Abdullah Efendi b. Mehmed mahzarında ikrâr-1 sahîh-i şer'î ve i'tirâf-ı sarîh-i mer'î [28a] idüp vâkıf-ı mûmâ-ileyhin akāra tebdîlini şart eylediği nukûd-1 mevkûfe ile iştirâ olunan sâlifü'z-zikr Silistre'de Gümrük kurbunda Tuna kenarında vâki‘ bir tarafdan Keçecizâde Hân'ı ve bir tarafdan sâhil-i Tûna ve iki tarafdan tarîk-i âm ile mahdûd bir birine muttasıl duvarları kârgîr dokuz bâb balıkçı mahzenleri ve üzerlerinde ikişer bâb oda ve bir sofayı ve dört kenîf ve havlu ve bir fırını müştemil on altı bâb müte'ehhilîn [28b] odaları ve yine Medîne-i mezbûre iskelesinde vâki' bir tarafdan Mustafa Ağa mülkü hân ve üç tarafdan tarîk-i âm ile mahdûd ma'lûmü'lmüştemilât Gümrükhâne ve mahmiye-i İstanbul'da Dâye Hâtûn Mahallesi'nde vâki' bir tarafdan Ruznamçeci Süleyman Efendizâde mülkü ve bir tarafdan El-Hâc İbrahim mülkü ve bir tarafdan sâbıkān hâs âhır halîfesi Osman Ağa zevcesi menzili ve bir tarafdan tarîk-i âm ile mahdûd [29a] tûlen ve arzan bi-hesâb-1 terbî'î dört yüz kırk zirâ' arsa üzerinde mebnî dâhiliyede fevkānî beş bâb oda ve bir sofa ve bir kiler ve iki tahta pûş ve tahtânî iki bâb oda ve bir kiler ve bir matbah ve bir hammâm ve kenîf ve bi'r-i mâ ve havlu ve hâriciyyede fevkānî bir bâb oda ve kenîf ve tahtânî bir anbâr ve somathâne ve ahırı müştemil bir bâb mülk menzîl ve yine mahmiye-i mezbûrede Kumkapı kurbunda Muhsine Hâtûn Mahallesi'nde [29b] vâki' bir tarafdan vakf-1 mezbûrdan Ahmed Çelebi menzîli ve bir tarafdan Bekir Pâşâ odaları ve iki tarafdan tarîk-i hâs ile mahdûd terbî‘an altmış üç zirâ' arsa üzerinde mebnî fevkānî bir oda ve bir sofa ve bir kenîf ve tahtânî bir bâb oda ve bir kenîf ve havluyu müştemil bir bâb mülk menzil ve yine mahalle-i mezbûrede vâki' bir tarafdan vakf-ı mezbûrdan menzil ve bir tarafdan Unyarıcı Halil nâm [30a] kimesne menzili ve bir tarafdan Bekir Paşa odaları ve bir tarafdan tarîk-i hâs ile mahdûd tûlen ve arzan be-hesâb-1 terbî'î seksen sekiz buçuk zirâ' arsa üzerinde mebnî fevkānî bir bâb oda ve tahtânî bir bâb oda ve birinde bir sofa ve birinde iki aded sofa ve vakf bi'r-i mâ üzerinde ocaklı bir bâb oda ve bir matbah ve bir tahtabend ve iki kenîfi ve yine bir bi'r-i mâyı müştemil birbirine muttasıl iki bâb mülk menzili [30b] ve yine mahalle-i mezbûrede vâki' bir tarafdan vakf-1 mezbûrdan Mehmed Çelebi tasarrufunda olan menzil ve bir tarafdan İbrahim Çelebi menzili ve bir tarafdan Ebûbekir Paşa odaları ve bir tarafdan tarîk-i hâs 


\section{I Nuran ÇETIN}

ile mahdûd tûlen ve arzan bi-hesâb-1 terbî'î altmış beş zirâ' üzerine mebnî fevkāni bir oda ve bir sofa ve tahtânî bir bab oda ve kenîf ve havluyu müştemil bir bâb mülk menzil ve yine mahmiye-i mezbûrede Kâtib [31a] Muslihiddin Mahallesi'nde vâki' iki tarafdan Kolancı İsmail menzili ve bir tarafından İbrahim Çelebi menzili ve bir tarafdan tarîk-i hâs ile mahdûd tûlen ve arzan bi-hesâb-1 terbî̂̂̀ elli altı zirâ' arsa üzerinde mebnî fevkānî iki bâb oda ve bir sofa ve tahtânî bir matbah ve bir Kenîf ve havluyu müştemil bir bâb mülk menzili ve yine mahalle-i mezbûrede vâki' bir tarafdan Halime Hâtûn menzili ve bir tarafdan Çıkrıkçı Mehmed Çelebi menzili [31b] ve iki tarafdan tarîk-i hâs ile mahdûd terbî'an iki yüz on altı zirâ' arsa üzerinde mebnî fevkānî iki bâb oda ve bir sofa ve bir kenîf ve tahtânî bir oda ve bi'r-i mâ ve kenîf ve havluyu müştemil bir bâb mülk menzil ve yine mahmiye-i mezbûrede Tevki'î Cafer Mahallesi'nde vâki' bir tarafdan Menûşa Nasrâniyye menzili ve bir tarafdan Bakkal Nikola menzili ve bir tarafdan Sandalcı Zimmî menzîli ve bir tarafdan tarîk-i âm ile [32a] mahdûd terbî'an iki yüz zirâ' arsa üzerinde mebnî ulyâda iki bâb oda ve bir sofa ve vustâda iki bâb oda ve sofa ve süflâda kārgîr mahzen ve bi'r-i mâ ve kenîf ve bahçe ve havluyu müştemil bir bâb mülk menzil ve yine mahmiye-i mezbûrede Molla Hüsrev Mahallesi'nde vâki’ iki tarafından Takyeci ElHâc Halil menzili ve bir tarafından Balcı Ali menzili ve bir tarafdan tarîki âm ile mahdûd terbî‘ an otuz zirâ' arsa [32b] üzerinde mebnî fevkānî bir bâb oda ve sofa ve kenîf ve havluyu müştemil bir bâb mülk menzil ve yine mahmiye-i mezbûrede Müftü Ali Mahallesi'nde vâki' bir tarafdan Hayyatlızâde menzili ve bir tarafdan Sâlih Efendizâde menzili ve bir tarafdan Süleyman Beşir menzili ve bir tarafdan tarîk-i âm ile mahdûd tûlen ve arzan be-hesâb-1 terbî'î iki yüz zirâ' arsa üzerinde mebnî fevkānî ve tahtânî iki bâb oda ve bir sofa ve bahçe [33a] ve müştemilât-1 sâ'ire-i ma'lûmeyi hâvî bir bâb mülk menzil ve yine mahmiye-i mezbûrede Edirnekapısı kurbunda Çakır Ağa Mahallesi'nde vâki' bir tarafından Notî bint-i Manol Nasrariyye menzili ve bir tarafında Rum Kilisesi ve bir tarafdan bahçe ve bir tarafdan Bağcı Kaba menzili ve tarîk-i âm ile mahdûd terbî'ân elli zirâ' arsa üzerinde mebnî fevkānî bir bâb oda ve bir matbah ocâğ 1 ve bir kenîfi müştemil bir bâb mülk menzil [33b] ve yine mahmiye-i mezbûre hısnı ebvâbından Ayvansarây Kapısı dâhilinde Mustafa Paşa-yı Atîk Mahallesi'nde vâki‘ bir tarafdan cidâr-1 hisn ve bir tarafdan Menkeşe Azmini menzili ve bir tarafdan Rum arsası ve bir tarafdan tarîk-i âm ile mahdûd terbî‘an üç yüz otuz zirâ' arsa üzerinde 
mebnî tabaka-i selâsede on iki bâb oda ve üç kenîf ve iki matbah ve hamâm ve bi'r-i mâ ve mahzeni müştemil bir bâb mülk menzil ve Medîne-i [34a] Hazret-i Ebî Eyüb Ensârî -radiye anhü Rabbihi'l-bârîdeUluca Baba Mahallesi'nde vâki' bir tarafdan müezzin Abdülkerim Çelebi menzili ve bir tarafdan Birincizâde menzili ve bir tarafdan Fatıma Hâtûn menzili ve bir tarafdan tarîk-i âm ile mahdûd ve be-hesâb-1 terbî‘̂̀ iki yüz yirmi beş zirâ' arsa üzerinde mebnî fevkānî bir bâb oda ve bir sofa ve bir matbah ve kenîf ve bi'r-i mâ ve bir mikdâr havluyu müştemil bir bâb mülk menzil ve havâss-1 refî́a [34b] Kazâsı'na tâbi' kasaba-i Hasköy'de El-Hâc Şa'bân Mahallesi'nde vâki' bir tarafdan Protakal cemâ‘ati odaları ve bir tarafdan Menâhim Yahûdî menzili ve iki tarafdan tarîk-i âm ile mahdûd terbî‘an bin yirmi dört zirâ' arsa üzerinde mebnî fevkānî ve tahtânî on dokuz bâb odalar ve kenîfler ve havlu ve müştemilât-ı sâire-i malûmeyi hâvî Yahûdihâne ta'bir olunur bir bâb mülk menzil ve kasabai mezbûrede Abdüsselam [35a] Mahallesi'nde vâki' bir tarafdan Marderdes zimmî menzili ve iki tarafdan Es-Seyyid Ahmed Beşe menzili ve bir tarafdan tarîk-i âm ile mahdûd terbî'an üç yüz on iki zirâ' arsa üzerinde mebnî tabaka-i selâsesinde beş bâb oda ve iki matbah ve bi'r-i mâ ve kenîf ve tahtında bir bakkâl dükkânı müştemil bir bâb mülk Yahûdihâne ve yine kasaba-i mezbûrede Turşucu Mahallesi'nde vâki’ bir tarafdan Çelenk İton menzili [35b] ve bir tarafdan Uzun Yahûdî mülkü ve bir tarafdan Mecdîzâde veresesi mülkü ve bir tarafdan tarîk-i âm ile mahdûd terbî‘an iki yüz on zirâ' arsa üzerinde mebnî tabaka-i selâsesinde üç bâb oda ve bir matbah ve bir kenîf ve bi'r-i mâ ve yine ittisâlinde tabaka-i selâsesinde altı bâb oda ve matbah ve kenîf ve havluyu müştemil birbirine muttasıl iki bâb Yahûdihâne ve mahrûsa-i Galata'ya tâbi' [36a] kasaba-i Kasımpaşa'da El-Hâc Ahmed Mahallesi'nde vâki'bir tarafdan Ahmed Efendi mülkü ve bir tarafdan müteveffâ El-Hâc Ahmed Ağa Bahçesi ve bir tarafdan Âişe Hâtûn mülkü ve bir tarafdan tarîk-i âm ile mahdûd ve terbî'an beş yüz otuz beş zirâ' arsa üzerinde mebnî fevkānî iki bâb oda ve bir sofa ve dehlîz ve tahtânî bir matbah ve bir kebîr müşterek bi'r-i mâ ve bir mikdâr bahçeyi müştemil [36b] bir bâb mülk menzil ve yine kasaba-i Tophâne'de Hoca Ali Mahallesi'nde vâki'bir tarafdan El-Hâc İbrahim menzili ve bir tarafdan Emine Hâtûn menzili ve bir tarafdan Abdullah Reîs menzili ve bir tarafdan tarîk-i hâs ile mahdûd ve tûlen ve arzan be-hesâb-1 terbî̂̂̂ yalnız beş yüz kırk iki zirâ' arsa üzerinde mebnî tabaka-i ulyâda iki bâb oda ve bir sofa ve bir kasr ve bir kenîf ve tabaka-i vüstâda bir bâb oda ve bir bâb [37a] sağîr 
96 | Nuran ÇETİN

oda ve bir matbah ve bir sobalı hammâm ve bir kenîf ve süflâda bir mahtab ve bir kenîf ve bir bi'r-i mâ ve bir kiler ve bahçeyi müştemil bir bâb mülk menzili ve yine mahmiye-i İstanbul'da Gül Cami'i Mahallesi'nde vâki'bir tarafdan Çavuşzâde veresesi menzili ve ba'zan Sirkeci Tekyesi Vakfı menzili ve bir tarafdan Osman Ağa menzili ve iki tarafdan tarîk-i âm ile mahdûd tûlen [37b] ve arzan be-hesâb-1 terbî'î yalnız beş yüz elli zirâ' arsa üzerinde mebnî dâhiliyeden fevkānî iki bâb oda ve dehlîz ve tahtânî bir oda ve bir matbah ve bir kiler ve bir kenîf ve tahtabend ve hâriciyyede iki bâb fevkānî oda ve dehlîz ve tahtında ahır ve bir kenîf ve iki bi'r-i mâ ve bir mikdâr bahçeyi müştemil mülk menzili ve yine mahmiye-i İstanbul'da Balat Kapısı [38a] dâhilinde Hoca Ali Mahallesi'nde vâki'bir tarafdan Terzi Ohân zimmî menzili ve bir tarafdan Terzi Sekbâz zimmî menzili ve iki tarafdan tarîk-i âm ile mahdûd tûlen ve arzan be-hesâb-1 terbî'î yalnız iki yüz yirmi beş zirâ' arsa üzerinde mebnî dâhiliyyede fevkānî üç bâb oda ve iki sofa ve bir dehlîz ve tahtânî bir oda ve bir matbah ve bir kiler ve bir dehlîz [38b] ve bir kenîf ve bir mikdâr havlu ve hâriciyyede tahtânî iki bâb oda ve bir sofa ve bir kenîf ve bir ahırı müştemil mülk menzili ve yine mahmiye-i İstanbul'da Ebâ Ensârî Kapısı dâhilinde Tokludede Mahallesi'nde vâki'bir tarafdan Hasekî Mehmed Ağa menzili ve bir tarafdan Seyyid Mehmed menzili ve bir tarafdan değirmen ve ba'zan Kuhûrcu mahzenîve bir tarafdan tarîk-i âm ile [39a] mahdûd yalnız beş yüz elli zirâ' arsa üzerinde mebnî fevkānî üç bâb oda ve iki sofa ve bir mikdâr divânhâne ve bir kiler ve bir kenîf ve tahtânî bir bâb kuhûd mahzenî ve ittisâlinde bir bâb oda ve bir kiler ve bir kenîf ve bir bi'r-i mâ ve bahçeyi müştemil mülk menzili ve yine mahmiye-i İstanbul'da Çıkrıkçı Kemâl Mahallesi'nde vâki' bir tarafdan Çıkrıkçı [39b] Kemal Mescid-i şerîfinin vakfından attâr dükkânı ve bir tarafdan Mes'udzâde Efendi zevcesi menzili ve bir tarafdan Etmekçi Fırını mahtabı ve bir tarafdan tarîk-i âm ile mahdûd üç kepenk bir bâb berber dükkânı ve yine Kasımpaşa'da Seferikoz Mahallesi'nde vâki'bir tarafdan Tosyalı Mustafa Kaptan menzili ve bir tarafdan Süleyman Kaptan menzili [40a] ve bir tarafdan Cinali Kaptan menzili ve bir tarafdan tarîk-i âm ile mahdûd dört yüz yirmi zirâ' arsa üzerinde mebnî fevkānî iki oda ve bir sofa ve bir matbah ve tahtânî iki oda ve dehlîz ve kenîf ve bir mağsel ve bir bi'r-i mâ ve bahçeyi müştemil bir bâb mülk menzil ve yine kasaba-i Kasımpaşa'da Ber Değirmenli Mahallesi'nde [40b] vâki'bir tarafdan Takyeci Mustafa menzili ve üç tarafdan tarîk-i âm ile mahdûd yüz seksen zirâ' arsa 
üzerine mebnîfevkānî bir bâb oda ve bir sofa ve dehlîz ve tahtânî bir bâb oda ve bir sofa ve bir mağsel ve bir bi'r-i mâ ve bir kenîf ve bir mikdâr havluyu müştemil bir bâb mülk menzil ve yine mahmiye-i İstanbul'da [41a] Tercümân Yûnus Mahallesi'nde vâki’bir tarafdan Müderris EsSeyyid Süleyman Efendi menzili ve bir tarafdan Es-Seyyid Alemdâr menzili ve bir tarafdan Mehmed Çavuş menzili ve bir tarafdan tarîk-i âm ile mahdûd tûlen ve arzan be-hesâb-1 terbî'î dört yüz zirâ' arsa üzerinde mebnîfevkānî üç bâb oda ve bir matbah ve bir tahtabend ve tahtânî iki bâb oda ve bir dehlîz ve bi'r-i mâ ve bahçe ve iki [41b] sokak kapısını müştemilbir bâb mülk menzil ve yine kasaba-i Kasımpaşa'da Yeldeğirmeni Mahallesi'nde vâki'bir tarafdan Ahmed Çavuş menzili ve bir tarafdan Kalaycı Hânı menzili ve bir tarafdan Kilci kızı menzili ve bir tarafdan tarîk-i âm ile mahdûd tûlen ve arzan be-hesâb-1 terbî'î yüz elli zirâ' arsa üzerine mebnî fevkānî iki bâb oda ve bir sofa ve tahtânî bir oda [42a] ve bir bi'r-i mâ ve eşcâr-1 müsmireli bahçeyi müştemil bir bâb mülk menzil ve yine kasaba-i Kasımpaşa'da Tahtakadı Mahallesi'nde vâki'bir tarafdan Sinân Kaptan menzili ve bir tarafdan Osman Beyefendi menzili ve bir tarafdan Dellâk Mustafa menzilleri ve bir tarafdan tarîk-i hâs ile mahdûd tûlen ve arzan be-hesâb-1 terbî̀̂̀ üç yüz elli zirâ' arsa üzerinde mebnî fevkānî[42b] dört bâb oda ve bir sofa ve bir matbah ve bir mağsel ve vüstâda bir bâb oda ve tahtânî iki bâb oda ve bir matbah ve bi'r-i mâ ve iki kenîf ve havluyu müştemil mülk menzil ve yine mahmiye-i İstanbul'da Hızırbey Mahallesi'nde vâki'bir tarafdan El-Hâc Yûsuf menzili ve bir tarafdan El-Hâc Mehmed menzili ve iki tarafdan tarîk-i âm ile mahdûd tûlen ve arzan be-hesâb-1 terbî'î iki yüz zirâ' arsa [43a] üzerinde mebnî dâhiliyede fevkānî üç bâb oda ve iki sofa ve bir tahtabend ve tahtânî bir matbah ve bir kiler ve bir bi'r-i mâ ve bahçe ve hâriciyede bir bâb fevkānî oda ve tahtında ahır üç tarafdan taş duvarları müştemil mülk menzili ve yine İstanbul'da Muhsine Hâtûn Mahallesi'nde vâki' bir tarafdan Mustafa Efendi menzili ve bir tarafdan Kebâbcı Mehmed Beşe [43b] menzili ve bir tarafdan Paşa Mustafa menzili ve bir tarafdan tarîk-i hâs ile mahdûd tûlen ve arzan be-hesâb-1 terbî'î yüz yirmi zirâ' arsa üzerinde mebnî fevkānî iki bâb oda ve bir dehlîz ve vüstâda iki bâb oda ve bir mağsel ve bir kenîf ve tahtânî bir matbah ve bir mikdâr havluyu müştemil mülk menzili ve yine mahmiyei İstanbul'da Defterdâr Ahmed Çelebi Mahallesi'nde vâki'bir tarafdan Nefise [44a] Hâtûn menzili ve bir tarafdan vakf-1 âhardan müte'ehhilîn odaları ve bir tarafdan tarîk-i hâs ve bir tarafdan tarîk-i âm ile mahdûd 
98 | Nuran ÇETIN

tûlen ve arzan be-hesâb-1 terbîî yüz elli zirâ' arsa üzerinde mebnî fevkānî iki bâb oda ve bir sofa ve vustâda bir matbah ve bir kenîf ve tahtında iki kepenkli bir hallâc dükkânı ve kezâlik iki kepenkli bir manav dükkânı ve bir mikdâr bahçeyi müştemil mülk menzili ve yine [44b] mahrûsa-i Galata'ya tâbi' kasaba-i Kasımpaşa'da Çatma Mescid Mahallesi'nde vâki'bir tarafdan Tersâne'de Barut Kâtibi Murtazâ Efendi menzili ve bir tarafdan Yağlıkçı El-Hâc Mustafa menzili ve bir tarafdan müezzin meşrûtası menzili ve bir tarafdan Medîne-i Münevvere Vakfi'ndan arsa ve bir tarafdan tarîk-i âm ile mahdûd tûlen ve arzan behesâb-1 terbî'î iki bin dokuz yüz elli beş zirâ' arsa [45a] üzerinde mebnî fevkānî dört bâb oda ve dehlîz ve tahtânî bir hammâm ve câmekān ve ittisâlinde fevkānî iki oda ve bir matbah ve bir bi'r-i mâ ve bir kenîf ve bahçeyi müştemil birbirine muttasıl iki bâb mülk menzili ve yine mahmiye-i İstanbul'da Muhtesib İskender Mahallesi'nde vâki'bir tarafdan Muhtesib İskender Câmi'-i şerîfi ve bir tarafdan Muytab Ömer Beş menzili ve bir tarafdan [45b] ba'zan Nalçacı zevcesi Hatice Hâtûn ve ba'zan Mehmed Çelebi ve ba'zan Câbirzâde zevcesi menzilleri ve bir tarafdan tarîk-i âm ile mahdûd tûlen ve arzan be-hesâb-1 terbi'î sekiz yüz zirâ' arsa üzerinde mebnî dâhiliyyede fevkānî iki bâb oda ve bir sofa ve bir sağîr oda ve tahtında matbah ve bi'r-i mâ ve hâriciyede fevkānî bir bâb oda ve tahtında ahır ve kenîf [46a] ve iki tarafı taş duvarlı bahçeyi müştemil mülk menzili ve yine mahrûsa-i Galata'ya tâbi kasaba-i Kasımpaşa'da Çatma Mescid Mahallesi'nde vâki'bir tarafdan Arab ElHâc Mehmed menzili ve bir tarafdan Buğdaycı El-Hâc Mehmed menzili ve bir tarafdan Kundakçı Mustafa Beşe menzili ve bir tarafdan tarîk-i âm ile mahdûd tûlen ve arzan be-hesâb-1 terbî'î yalnız iki yüz otuz zirâ' arsa [46b] üzerinde mebnî fevkānî üç bâb oda ve bir sofa ve tahtânî bir oda ve bir bi'r-i mâ ve bir mikdâr havluyu müştemil bir bâb mülk menzili ve yine mahmiye-i İstanbul'da Kocamustafapaşa Mahallesi'nde vâki' Sulu Manastır kurbunda kāin bir tarafdan Makascı Serkis zimmî menzili ve bir tarafdan Habar zimmî menzili ve bir tarafdan Câmcı Mardoros zimmî menzilî ve bir tarafdan tarîk-i âm ile mahdûd tûlen ve arzan behesâb-1 [47a] terbî'î yalnız iki yüz elli zirâ' arsadan yüz altmış zirâ'ı üzerinde mebnî tabaka-i ulyâda iki bâb oda ve matbah ve dehlîz ve vustâda iki bâb oda ve matbah ve dehlîz ve tahtânî bir matbah ve mahtab ve bi'r-i mâ ve mesfûr Makascı zimmî Serkis tarafından taş duvarı ve bir mikdâr eşcârlı bahçeyi müştemil mülk menzil ile mâ'adâ doksan zirâ' arsa üzerinde mebnî [47b] tabaka-i ulyâda bir bâb oda ve bir 
câmlı köşk ve bir matbah ve dehlîz ve vustâda bir bâb oda ve dehlîz ve tahtânî matbah ve bir kârgîr mahzen ve kenîf ve havluyu müştemil birbirine muttasıl iki bâb mülk menzilleri ve yine mahmiye-i İstanbul'da Abdi Çelebi Mahallesi'nde vâki' bir tarafdan Terzi Haçdor zimmî menzili ve bir tarafdan Saatçi Serkis zimmî menzilî ve bir tarafdan Pâçâcı [48a] veresesi tasarruflarında olan vakf-ı âhardan menzil ve bir tarafdan tarîk-i hâs ile mahdûd tûlen ve arzan be-hesâb-1 terbî‘̂̂ yalnız yüz otuz üç zirât arsa üzerinde mebnî fevkānî iki bâb oda ve dehlîz ve tahtânî bir oda ve bi'r-i mâ ve kenîf ve havluyu müştemil bir bâb mülk menzili ve yine mahmiye-i İstanbul'da Sulu Manastır kurbunda Hâce Hâtûn [48b] Mahallesi'nde vâki' bir tarafdan Terzi İsrâil zimmî menzilî ve bir tarafdan Kuyumcu Evanes zimmî menzili ve bir tarafdan Terzi Evanes zimmî menzili ve tarafdan tarîk-i âm ile mahdûd tûlen ve arzan behesâb-1 terbî'î yalnız yüz on iki zirâ' arsa üzerinde mebnî fevkānî iki bâb oda ve bir matbah ve dehlîz ve vustâda iki bâb oda ve bir matbah ve dehlîz ve tahtânî bir matbah ve bi'r-i mâ [49a] ve kenîf ve havluyu müştemil bir bâb mülk menzil ve yine mahmiye-i İstanbul'da Yenibahçe kurbunda Kaptan Sinân Paşa Mahallesi'nde vâki' iki tarafdan El-Hâc Ömer menzili ve bir tarafdan tarîk-i hâs ve bir tarafdan tarîk-i âm ile mahdûd tûlen ve arzan be-hesâb-1 terbî'î yalnız üç yüz seksen zirâ' arsa üzerinde mebnî dâhiliyede fevkānî iki bâb oda ve bir sofa ve dehlîz ve bir kenîf ve bir mağsel [49b] ve bir tahta-pûş ve tahtânî bir bâb oda ve bir matbah ve bir kiler ve üç tarafdan taş duvar ve bahçe ve hâriciyyede fevkānî iki bâb oda ve dehlîz ve tahtında bir ahır ve kenîf ve bir mikdâr havluyu müştemil bir bâb mülk menzili ve yine mahmiye-i İstanbul'da Karagümrük kurbunda Muhtesib İskender Mahallesi'nde vâki' bir tarafdan Mumcu İsmail Çelebi menzili ve bir tarafdan [50a] Muhzır Mehmed Çelebi menzili ve bir tarafdan Serlüce Kuzât-1 Anadolu Halil Efendi menzili ve bir tarafdan Mustafa Çelebi menzili ve bir tarafdan tarîk-i âm ile mahdûd tûlen ve arzan be-hesâb-1 terbî̀̂̂ yalnız üç yüz yirmi zirâ' arsa üzerinde mebnî dâhiliyyede fevkānî iki bâb oda ve bir sofa ve dehlîz ve vüstâda iki bâb oda ve bir dehlîz ve tahtânî bir kârgîr matbah ve bi'r-i mâ ve bahçe ve hâriciyyede [50b] fevkānî bir bâb oda ve bir sofa ve bir kenîf ve tahtında ahır ve cevânib-i erba'ası tâş duvârları müştemil bir bâb mülk menzil ve yine mahrûsa-i Galata'ya tâbi' kasaba-i Kasımpaşa'da Kulaksız Mahallesi'nde vâki' bir tarafdan Mehmed Ağa menzili ve bir tarafdan Süleyman Efendi menzili ve bir tarafdan Hâce oğlu İbrahim Beşe menzili ve bir tarafdan Muytâb El-Hâc Mehmed ve 
100 | Nuran ÇETIN

Besmâ oğlu İsmail menzilleri ve tarîk-i hâs ile mahdûd [51a] tûlen ve arzan be-hesâb-1 terbî'̂̀ yalnız sekiz yüz elli zirâ' arsa üzerinde mebnîfevkānî iki bâb oda ve bir sofa ve tahtânî bir bâb oda ve bir sofa ve bi'r-i mâ ve bahçe ve havluyu müştemil bir bâb mülk menzili ve yine mahmiye-i İstanbul'da Kocamustafapaşa Mahallesi'nde vâki' bir tarafdan Baltacı odaları ve bir tarafdan Hüdâverdî zimmî menzili ve bir tarafdan [51b] Katon Nasrâniyye menzili ve bir tarafdan tarîk-i hâs ile mahdûd tûlen ve arzan be-hesâb-1 terbî'î yalnız yüz yirmi zirâ' arsa üzerinde mebnî tabaka-i ulyâda bir cihannumâ bir oda ve tabaka-i vüstâda bir oda ve süflâda bir oda ve matbah ve kenîf ve bi'r-i ma ve bir mikdâr havluyu bir bâb mülk menzili ve yine mahmiye-i İstanbul'da Çakır Ağa Mahallesi'nde vâki' [52a] bir tarafdan Kürkçü Dako zimmî mülkü menzili ve bir tarafdan kilise ve iki tarafdan tarîk-i âm ile mahdûd tûlen ve arzan be-hesâb-1 terbî̀̂̂ yalnız yüz kırk beş zirâ' arsa üzerinde mebnî fevkānî iki bâb oda ve bir sofa ve bir matbah ve vüstâda iki bâb oda ve bir matbah ve bir sofa ve tahtânî bir kârgîr matbah ve bi'r-i mâ ve tahtında üç kepenkli bir dükkân ve tâş duvar ve havluyu müştemil [52b] bir bâb mülk menzili ve yine mahrûsa-i Galata'ya tâbi' kasaba-i Kasımpaşa'da Küçük Piyâle Paşa Mahallesi'nde vâki' bir tarafdan Râbia Hâtûn menzili ve bir tarafdan mahalle-i mezbûre müezzinine meşrûta menzil ve iki tarafan tarîk-i âm ile mahdûd tûlen ve arzan be-hesab-1 terbî‘̂i yalnız beş yüz yirmi beş zirâ' arsa üzerinde mebnî fevkānî iki bâb oda ve iki sofa ve kenîf [53a] ve tahtânî iki bâb oda ve bir mahtab ve bi'r-i mâ ve eşcâr-1 müsmire ve gayr-1 müsmireli bahçeyi müştemil bir bâb mülk menzili ve yine mahrûsa-i Galata'ya tâbi' kasaba-i Kasımpaşa'da Küçük Piyâle Paşa Mahallesi'nde vâki' bir tarafdan Yorğancı El-Hâc Ahmed menzili ve bir tarafdan Molla Hâtûn menzili ve bir tarafdan ve ba'zan Fatıma Hâtûn Vakfı [...] menzili ve ba'zan mescid-i şerîf havlusu ve bir tarafdan [53b] tarîk-i âm ile mahdûd tûlen ve arzan be-hesâb-1 terbî'i yalnız altı yüz zirâ' arsa üzerinde mebnî tabaka-i ulyâda bir bâb oda ve sofa ve tabaka-i vüstâda bir bâb oda ve bir sofa ve süflâda kiler ve yine kapı üzerinde fevkānî bir bâb oda ve bir sofa ve kenîf ve bi'r-i mâ ve eşcâr-1 müsmire ve gayr-1 müsmireli bahçeyi müştemil bir bâb mülk menzilî ve yine mahmiye-i İstanbul'da [54a] Müftü Ali Mahallesi'nde vâki' bir tarafdan Ahmed Çelebi menzili ve bir tarafdan Halil Çelebi menzili ve bir tarafdan tarîk-i hâs ve bir tarafdan tarîk-i âm ile mahdûd tûlen ve arzan be-hesâb-1 terbî̀̂̀ yalnız dört yüz yetmiş zirâ' arsa üzerinde mebnî fevkānî bir bâb oda ve bir matbah ve dehlîz ve tahtabend 
ve kenîf ve tahtânî bir bâb oda ve kenîf ve bi'r-i mâ ve eşcâr-1 müsmire ve gayr-1 müsmireli bahçeyi müştemil bir bâb mülk menzili [54b] ve yine mahmiye-i İstanbul'da Küçükmustafa Paşa kurbunda Mollâ Hüsrev Mahallesi'nde vâki' bir tarafdan Keleş Mustafa menzili ve bir tarafdan Balmumcu zevcesi Âişe Hâtûn menzili ve bir tarafdan Tüfenkçî menzili ve bir tarafdan tarîk-i âm ile mahdûd tûlen ve arzan be-hesâb-1 terbî'̂̂ yalnız iki yüz yirmi zirâ‘ arsa üzerinde mebnî fevkānî bir bâb oda ve bir sofa ve bir matbah ve tahtabend ve tahtânî bir bâb oda ve bi'r-i mâ [55a] ve bahçe ve üç tarafdan taş duvarları müştemil bir bâb mülk menzili ve yine mahrusa-i Galata'ya tâbi' kasaba-i Kasımpaşa'da El-Hâc Hüsrev Mahallesi'nde vâki' etrâf-1 erba'ası Sarı Mehmed bahçesi ve Hâcer Hâtûn ve Ali Çavuş ve Mehmed Çavuş ve Hakkâk İbrahim ve Berber Süleyman ve Hakkâk Mehmed ve Bozacı Mehmed ve Âşık Halîl ve Ebe Hâtûn mülkleri ve tarîk-i hâs ile mahdûd tûlen ve arzan [55b] be-hesâb-1 terbî'̂̂ yalnız sekiz bin zirâ' arsalı tahtânî bir köşk ve bir kârgîr oda ve eşcâr-1 müsmire ve [...]bahçe ve iki bi'r-i mâ ve iki sokak kapısını müştemil mülk ipçi kârhâne ve yine mahmiye-i İstanbul'da Avratpazarı kurbunda Canbâziyye Mahalellesi'nde vâki' bir tarafdan Sandalcı Abdullah Beşe menzilî ve bir tarafdan Yûsuf Ağa menzili ve bir tarafdan Hatice Hâtûn menzili ve bir tarafdan tarîk-i âm ile mahdûd [56a] tûlen ve arzan behesâb-1 terbî̀̂̂ yalnız yüz elli zirâ' arsa üzerinde mebnî fevkānî bir bâb oda ve bir sofa ve tahtânî bir oda ve kenîf ve havlu ve üç tarafdan taş duvarları müştemil bir bâb mülk menzili ve yine mahmiye-i İstanbul'da Avratpazarı kurbunda Canbaziyye Mahallesi'nde vâki' bir tarafdan Sandalcı Arab menzilî ve bir tarafdan Camcı Ahmed menzilî ve bir tarafdan [56b] tarîk-i hâs ve bir tarafdan tarîk-i âm ile mahdûd tûlen ve arzan be-hesâb-1 terbi'î yalnız yüz elli zirâ' arsa üzerinde mebnî tabaka-i ulyâda bir bâb oda ve bir sofa ve dehlîz ve vüstâda bir bâb oda ve bir matbah ve sofa ve bi'r-i mâ ve kenîf ve havluyu müştemil bir bâb mülk menzili ve yine mahmiye-i İstanbul'da Demirkapı kurbunda Elvân Mahallesi'nde vâki' iki tarafdan El-Hâc Halil Vakfi'ndan [57a] Mustafa ve Hasan tasarruflarında olan iki bâb menzil ve bir tarafdan Abdülbâkî Ağa veresesi mülkleri ve bir tarafdan tarîk-i hâs ile mahdûd tûlen ve arzan be-hesâb-1 terbî'î yalnız yüz yirmi zirâ' arsa üzerinde mebnî tabaka-i ulyâda iki bâb oda ve bir sofa ve bir tahte's-semâ ve vüstâda iki bâb oda ve bir sofa ve tahtânî bir matbah ve bir kenîf ve iki tarafdan taş duvarları [57b] ve iki tarafdan dahî mezbûrân Mustafa ve Hasan ile müşterek taş duvarı ve havluyu müştemil bir bâb mülk menzilî ve yine mahmiye-i 


\section{2 | Nuran ÇETIN}

İstanbul'da Yenibahçe kurbunda Dudu Latif Mahallesi'nde vâki' bir tarafdan Hâce Hâtûn menzili ve bir tarafdan Abdülgani Efendi menzili ve bir tarafdan Saatçi oğlu El-Hâc Mehmed menzili ve ba'zan Mehmed Efendi menzilî ve bir tarafdan yine Saatçi Mehmed Çelebi menzilî[58a] ve bir tarafdan tarîk-i âm ile mahdûd tûlen ve arzan be-hesâb-1 terbî'î yalnız iki bin elli altı zirâ' arsa üzerinde mebnî dâlihiyyede fevkānî üç bâb oda ve bir sofa ve bir kenîf ve tahtânî üç bâb oda ve bir kiler ve bir matbah ve iki kurnalı bir hammâm ve bir câmekān ve iki kenîf ve bir mikdâr havlu ve eşcâr-1 müsmire ve gayr-1 müsmireli bahçe ve bi'r-i mâ ve hâriciyyede fevkānî [58b] yedi bâb oda ve iki sofa ve dehlîz ve kenîf ve tahtânî beş bâb oda ve bir ahır ve somathâne ve iki kenîf ve bir su mahzenî ve eşcâr-1 müsmire ve gayr-1 müsmireli bahçe ve nısf mâsûra mâ-i lezîz-i cârîyi müştemil bir bâb mülk menzili vakf-1 sahîh-i müebbed ve habs-i sarîh-i muhalled ile vakf ve habs ve vakf-1 mezkûrlarına zamm ve ilhâk edip şöyle şart ve ta'yîn eyledi ki vâkıf-ı mûmâ-ileyhin bir kita [59a] vakfiye-i ma'mûlün bahâsında olan şurût ve kuyûd menâzil-i mezkûrda dahî cârî ola deyü ta'yîn-i şurût ve teybîn-i kuyûd edip menâzil-i mezkûreyi fâriğan mine'ş-şevâğıl mütevellî-i mezbûra teslîm ol dahî vakfiyyet üzre kabz ve teslîm ve sâir evkāf mütevellîleri gibi tasarruf eyledi dedikde gibbe't-tasdîki'l-mu'teber [...] eimme-i selâse-i ahyâr -rahimehumullâhi'l-meliki'l-gaffâr- beynlerinde vakfın [59b] sıhhat ve lüzûmu husûsunda olan ihtilâfa binâen kāimakām-1 mezbûr ile mütevellî-i merkûm Abdullah Efendi rücû' ve istirdâd ve imtinâ' da'vâsıyla hâkim-i muvakkı'-1 sadr-1 kitâb huzûrunda ba'de't-terâfü' hâkim-i mûmâ-ileyh -esbağallâhü ni'amehû aleyhi- tarafeynin kelâmina nazar ve "mennâ'in li'l-hayri" olmakdan hazer edip âlimen bi'l-hilâf beyne'l-eimmete'l-eşrâf alâ kavl-i men-yerâh vakf-1 mezbûrun sihhat ve lüzûmuna hükm-i sahîh-i şerî̀ ve kazâ-i sarîh-i mer'î edip min bâ'd vakf1 mezbûr [60a] sahîh ve lâzım ve sarîh ve mütehattemir olup nakz ve nakîzine mecâl muhâl oldu. Cerâ zâlike ve hurrire fî gurreh Cumâde'lûlâ sene ihdâ ve sittîn ve mi'e ve elf min-hicreti men lehü'l-izzü ve'ssa'âde ve'ş-şeref

Şuhûd:

Efdalü'l-ulemâ El-Hâc Mahmûd Efendi b. Halil Hâce-i vakf, İmâm1 Mahmudpaşa Feyzullah Efendi b. Hüseyin, Kâtib hazi'l-evkāf Hâfız Sâlih b. Osman, Hâce Osman Efendi tâbi'-i vâkıf Murtazâ Efendi, Ata b. Karaca Ahmed Çelebi b. Halil, Kerestecizâde El-Hâc Mustafa b. El-Hâc İsmail, Hasan b. Abdurrahman tâbi'-i vâkıf Ahmed Efendi El-Hac 
Alizâde, El-Hâc Bedri Ağa b. Nusah, El-Hâc Mehmed b. Halil, Üsküdârî Mustafa Ağa b. Hasan, Hasan b. Abdurrahman tâbi'-i vâkıf, Ali b. Mustafa, El-Hâc Ali b. Hüseyin, El-Hâc Yûsuf b. Abdullah kâtib-i vakf, El-Hâc Halil b. Mustafa câbî-i vakf, El-Hâc Mehmed b. Halil, Uzun Ali b. Osman, Berber Abdullah b. Abdurrahman, El-Hâc Ahmed b. Mehmed

[61a] Limâ tâla'tü bimâ fîhi mine'l-vakfi ve't-tescîl veceduhû cedîren li'l-hayri ve's-sebil nemekahû el-fakîr ileyhi azze sübhânehû ve te’âlâ Şeyhzâde Es-Seyyid Mehmed Refî' el-Müfettiş-i bi-umûr-i evkāfi'lHarameyni'l-muhteremeyn -gufira lehümâ-

Mâ fîhi mine'l-vakfi ve't-tescîl vaka'a indî nemekahû el-abdü'lfakîr-i ileyhi azze şânuhû Ömer b. Abdülkerim b. Ali el-müvelle'l-hilâfe bi-dâri's-saltanati's-seniyye -gufira lehüm-

[61b] Selime Hanım'ın müceddeden vakf eylediği Kürsî Vakfı'nın müsakkafât vakfiyesidir.

Bismillahirrahmanirrahim

El-hamdü lillâhi Rabbi'l-âlemîn. Vessalâtü ve's-selâmü alâ seyyidinâ Muhammedin ve alâ âlihî ve sahbihi ecma'în. Emma ba'd işbû kitâb-1 sıhhat nisâbın tahrîr ve imlâ ve tastîr ve inşâsına bâ'is ve bâdî oldur ki Mahmiye-i İstanbul'da [62a] Mahmudpaşa Mahallesi'nde sâkine iken bundan akdem vedâ'-1 âlem-i fânî eden sâbıkān Tersane-i âmire emîni merhûm Murtazâ Efendi kerîmesi merhûme Selime Hanım karındaşı Halil Reşid Efendi'yi zikr-i âtî vesâyâsını tenfîze vasiyy-i muhtâr edip mezbûr Halil Reşid Efendi vesâyasını yerine getirmek üzere iken bi-emrillâhi te'âlâ ömrü vefâ etmemekle min-kıbeli'ş-şer'i'ş-şerîf bâhüccet-i şer'iyye [62b] vasiyy-i mansûbu ve babası merhûm-1 mûmâileyh Murtazâ Efendi Vakfi'na hâlâ mütevellî olan fahrü'l-akrân Mehmed Tâhir Efendi ibni'l-merhûm el-mezbûr Murtazâ Efendi tarafından husûs1 âti'l-beyânı ikrâra vekîl olduğu Şeyh Mustafa Efendi b. Hüseyin ve Molla Selim b. Mustafa şehâdetleriyle sâbit olan El-Hâc Yûsuf Ağa b. Abdullah meclis-i şer'-i şerîf-i [...] bi'l-vekâlete ikrâr ve takrîr-i kelâm edip [63a] merhûme-i mezbûre Selime Hanım hayâtında ben bi-emrillâhi te’âlâ vefât eylediğimde vakf olmak üzere sülüs mâlımdan iki bin yüz elli kuruş ifrâz ve meblağ-1 merkûme ile münâsib mahallerde akār iştirâ ve icâreteyn ile âhara îcâr olunup hâsıl olan gallesinden İstanbul'da Mahmudpaşa-yı Velî Câmi'-i şerifinde cemâ'at-i müslimîne va'z u nasîhat içün ulemâdan bir kimesne vâ'iz ta'yîn olunup [63b] yevmî on akçe vazîfe verile ve vakf-1 mezbûr babamız merhûm Murtazâ Efendi'nin Medîne-i Eyüb'de İdris Köşkü kurbunda binâ ve ihyâ eylediği 
104 | Nuran ÇETIN

Nakşibendiyye Zâviyesi Vakfi'na her kim mütevellî olur ise ol kimesne benim vakfıma dahî mütevellî ola ve vakf-ı merhûm babamız merhûmun vakfına zamm ve ilhâk oluna deyü vasiyyet ve tenfîzine müvekkilim karındaşı mûmâ-ileyhi vasiyy-i muhtâr ol dahî kabûl ve mezbûre [64a] Selime Hânım musırraten fevt ve meblağ-1 mûsâ-bih mezkûr sülüs terekesine müsâ'id olup ve müvekkilim mûmâ-ileyh meblağ-1 mûsâ-bih-i mezkûru sülüs terekesinden bi'l-vasâyâ ahz ve meblağ-1 merkûm ile bin yüz yetmiş beş senesi Şa'bân'ında İstanbul'da Kırkçeşme kurbunda Firuzağa Mahallesi'nde vâki' bir tarafdan Fatıma Hâtûn ve iki tarafdan İmâm Mehmed Efendi ve menzilleri ve bir tarafdan tarîk-i âm ile [64b] mahdûd terbî‘ân doksan bir zirâ' arsayı ve yevmî bir akçe icâre-i mü'ecceleye mütehemmil bir bâb menzil ve yine şehr-i mezbûrede mahalle-i merkûmede vâki' terbî' an yüz on beş zirâ' arsalı ulyâda bir oda ve vustâda bir oda ve bir sofa ve tahtânî matbah ve kenîf va havluyu müştemil ve yevmî bir akçe icâre-i mü'ecceleye mütehammil bir bâb menzil ve yine şehr-i mezbûrda Edirnekapısı dâhilinde [65a] Ali Paşa-yı Atîk Mahallesi'nde vâki' bir tarafdan Acı Evannes ve bir tarafdan Kabril ve bir tarafdan Yanaki ve ba'zan Yoseb menzilleri ve bir tarafdan tarîk-i âm ile mahdûd tabaka-i selâsede odaları ve havluyu müştemil ve yevmî bir akçe icâre-i mü'ecceleye mütehammil bir bâb menzil ve yine şehr-i mezbûrda Fenerkapısı dâhilinde Abdi Subaşı Mahallesi'nde vâki’ bir tarafdan Çuhadâr Kasım Ağa veresesi ve iki tarafdan tarîk-i âm ile mahdûd fevkānî [65b] üç oda ve bir sofa ve tahtânî bir oda ve kenîf ve matbah ve havluyu müştemil ve yevmî bir akçe icâre-i mü'ecceleye mütehammil bir bâb menzil ve yine şehr-i mezbûrda Şeyh Ferhad Mahallesi'nde vâki' bir tarafdan tarîk-i hâs ve iki tarafdan Harameyn-i şerîfeyn ve avârız vakıfları ve bir tarafdan tarîk-i âm ile mahdûd terbî‘an üç yüz on beş zirâ' arsalı tabaka-i ulyâda [66a] üç oda ve dehlîz ve sofa ve tahtında bir köşk ve iki oda ve mahzen ve matbah ve bi'r-i mâ ve sarnıç ve kenîf ve tahtında dört bâb dükkânları müştemil ve yevmî üç akçe icâre-i mü'ecceleye mütehammil bir bâb menzil ve yine sene-i mezbûre Şevvâl'inde İstanbul'da Mustafa Paşa Mahallesi'nde vâki' bir tarafdan bostan ve bir tarafdan Yorgi ve bir tarafdan kal'e duvarı ve bir tarafdan [66b]tarîk-i âm ile mahdûd fevkānî iki oda ve tahtânî iki oda ve bir kenîf ve müştemilât-ı sâireyi hâvî terbî‘ an iki yüz altmış zirâ' arsalı ve yevmî iki akçe icâre-i mü'ecceleye mütehammil bir bâb menzil ve yine sene-i mezbûre Şa'bân'ında Atpazarı kurbunda Manisalı Çelebi Mahallesi'nde vâki' bir tarafdan Mehmed Odabaşı ve bir tarafdan Es- 
Seyyid El-Hâc Mehmed ve bir tarafdan tarîk-i âm ile mahdûd [67a] terbî‘an yüz altmış iki zirâ‘ arsalı fevkānî iki bâb oda ve bir sofa ve dehlîz ve kemer matbah ve kiler ve kuyu ve mahzen ve havluyu müştemil ve yevmî bir akçe icâre-i mü'ecceleye mütehammil menzil ki cem'an yedi bâb menzili vakf-1 mezbûr içün vasiyy-i mûmâ-ileyhe bi'l-vesâye vakf olmak üzre iştirâ ve her birini mütehammil oldukları icâre-i mü'eccele-i mezkûre ile âhara îcâr ve câmi'-i mezkûrda va'z eylemek [67b] üzere ulemâdan bir kimesneyi yevmî on akçe vazîfe ile vâ'iz ta'yîn ve babası merhûm-1 mûmâ-ileyhin vakfına zam ve ilhâk ve bi't-tevliye kabz ve tesellüm edip bu vech üzere tenfîz vasiyet etmekle menâzil-i mezkûre min-gayr-1 mürâfa'atin velâ-muhâkemetin vakf olup nakz ve nakîzi adîmü'l-ihtimâl oldu. Cerâ zâlike ve hurrire fi'l-yevmi's-sânî ve'l-1şrîn min-Şevvâli'l-mükerrem li-sene hamse ve seb'în ve mi'e ve elf.

[68a] Şuhûdü'l-hâl:

Attâr Karaca İbrahim, Na'lband Hâce Ali Efendi, Osman Efendi, Şeyh Mustafa Kırîmî Efendi, El-Hâc Hasan, El-Hâc Halil Câbî, El-Hâc Mustafa, El-Hâc Ahmed Ağa, Ebubekir Ağa, Molla Hasan, El-Hâc Yûsuf Efendi, El-Hâc İsmail, Berber Hacı Abdullah

[68b] Tıbk-1 asluhû el-mümzî el-mahtûm harrarahû el-fakîrü ileyhi sübhânehû ve te'âlâ Ömer b. Abdülkerim el-müfettiş bi-Evkāfi'lHarameyni'l-muhteremeyn el-mükerremeyn -gufira lehümâ-

Uharrir bimâ zükire ve ta'addet mâ tahvîhi. Harrarahu el-fakîr-i ileyhi azze şânuhû bi-Yemliha Hasan el-Müvellâ hilâfetehû bi-mahkemet Mahmudpaşa bi-dâri'l-hilâfe-gufira lehu-

Bismillahirrahmanirrahim

El-hamdü lillâhi Rabbi'l-âlemin vessalâtü ve's-selâmü alâ rasulihi Muhammedin ve âlihî ve sahbihî ecma'în. Emmâ ba'd her âkil gâfil olmayıp zamân-ı âfiyetde âkıbet mülâhaza [69a] kılmağa müdâvemet "Ed-dünyâ mezra'atü'l-âhire" idiğin tefekkür "men câe bi'l-haseneti felehû aşru emsâlihâ" işârını zahmine merhem bilip "izâ mâte ibnü âdeme inkata'a amaluhû illâ an-selâsin. İlmün yenfe'u bihî ve veledün sâlihun yed'û lehû ve sadakatün câriyetün" hadîs-i şerîfinin mazmûn-1 münîfine vâkıfe olan İstanbul'da [69b] Mahmudpaşa-yı Veli Câmi'-i şerîfi kurbunda sâkine sâbikān Tersâne-i âmire Ruznâmçe-i evvel olan merhûm Murtazâ Efendi'nin halîlesi sâhibetü'l-hayrât ve'l-hasenât râğibetü'l-müberrâti'l-âliyât umdetü'l-muhadderât Behrî Hâtûn ibnete Abdullah b. Abdülmennân zikr olunan Mahmudpaşa-yı Velî[70a] Mahallesi'nde sâkine olduğu menzilinde taraf-1 şer'den me'zûnen bi'l- 
106 | Nuran ÇETIN

hükm irsâl olunan Abdülhalim Efendi b. Mehmed Efendi'nin zeyl-i kitâbda mektûbü'l-esâmî olan müslimîn huzûrunda akd eylediği meclis-i şer'-i şerîf-i Ahmedî ve mahfil-i dîn-i münîf-i Muhammedî'de zâtı imâm-1 mahalle-i merkûme Feyzullah [70b] Efendi b. El-Hâc Hüseyin Efendi ve Dersi'âm Osman Efendi b. Ahmed ve Attâr İbrahim Ağa b. Halil ta' rîfleriyle mu'arrefe olan mûmâ-ileyhâ Behrî Hâtûn zikr-i âtî vakfına liecli't-tescîl mütevellî nasb ve ta'yîn eylediği ümdetü'l-emâcid ve'l-ekârim sa'adetlü Giridî El-Hâc İbrahim Ağa b. [71a] El-Hâc Ahmed Ağa mahzarında ikrâr-1 sahîh-i şer'î ve i'tirâf-1 sarîh-i mer'î edip Medîne-i Hazret-i Ebî Eyüb El-Ensârî -aleyhi rahmeti'l-Bârî'de- İdris Köşkü kurbunda zevcem merhûm mûmâ-ileyh Murtazâ Efendi hayâtında meşâyih-i tarîk-i Nakşibendiyye'den Kutbü'l-ârifîn Gavsü'l-vâsılîn [71b] merhûm ve mağfûrun leh Eş-Şeyh Abdullah Efendi hazretleri içün müceddeden binâ ve ihyâ eylediği Nakşibendiyye Hânkāhı kurbunda arsa-i memlûkem üzerine mukaddemâ li-vechillâhi te'âlâ etfâl-i müslimîn içün binâ ve ihyâ eylediğim mekteb-i şerîf ile atyeb mâl ve ahsen menâlimden ifrâz eylediğim altı bin kuruşumu [72a] hasbeten lillâhi te'âlâ vakf-1 sahîh-i müebbed ve habs-i sarîh-i muhalled ile vakf ve habs ve zevcim merhûm-1 mûmâ-ileyh Murtazâ Efendi'nin Hânkāh-1 merkûme vakfına zam ve ilhâk ve şöyle şart eyledim ki meblağ-1 mezkûr ile münâsib mahallerde akār iştirâ ve icâreteyn-i misliyyeteyn ile îcâr ve hâsıla olan [72b] icâre-i mü'eccele ve mu'acceleden mârru'z-zikr mekteb-i şerîfde mu'allim-i sibyân kimesneye yevmî beş akçe vazîfe verile ve halîfe-i mekteb olan kimesneye yevmî iki akçe vazîfe verile ve zevcim mûmâ-ileyh Murtazâ Efendi'nin evkāfına kâtib ve câbî olan kimesneler benim vakfıma dahî kâtib ve câbî olup her [73a] birine yevmî bir akçe kitâbet ve cibâyet vazîfesi verile. Ve sâlifü'z-zikr hânkāhda ayda bir kere leyle-i isneynde hatm-i hâcegân olup akîbinde tabh-1 helvâ içûn yevmî on altı akçe verilip tenâvel olundukdan sonra kemâl-i keremlerinden bu fakîre ve zevcim mûmâ-ileyhin ve sadrî oğlum müteveffâ Halil Reşîd Efendi [73b] içûn üçer ihlâs-1 şerîf ve birer fâtiha-i şerîfe okunup sevâbını rûhumuza ihdâ ve hayır du'â buyuralar ve mukaddemâ tekye-i merkûmede câmi'-i şerîfde vakf-1 sahîh ile vakf ve sandık ile vaz' eylediğim bir kıt’a Kelâm-1 kadîm-i şerîf ve otuz aded eczâ-i kelâm-1 kadîm-i şerîfi iki kimesne tilâvet [74a] ve sevâbını benim ve zevcim mûma-ileyhin ve oğlum mûmâ-ileyh Halil Reşid Efendi'nin ve sâir cemî'i mü'minîn ve mü'minâtın rûhlarına ihdâ ve mukābelesinde Mushaf-1 şerîfi tilâvet eden kimesneye yevmî iki akçe ve eczâ-i şerîfeyi tilâvet eden 
kimesneye dahî yevmî iki akçe vazîfe verile ve vazîfe-i [74b] tevliyet yevmî bir akçe ola bi-fazlillâhi te'âlâ vakf-1 mezbûrda nemâ mütezâyid oldukda zikr olunan harc-1 helvâ yevmî altmış akçeye tekmîl olunup ayda dört def'a leyle-i isneynde minvâl-i meşrûh üzre helvâ tabh ve akîbi hatimde bulunan kimesneler it'âm oluna ve vezâif-i muharrere-i mezbûreye [75a] ma'rifet-i şer'le her birine mikdârınca vazîfe zam oluna ve vakf-1 mezbûrun tevliyeti vaziffe-i merkûmesiyle hayâtda oldukça bana meşrûta ola vefâtımdan sonra işbû mûmâ-ileyh Girîdî El-Hâc İbrahim Ağa'ya meşrûta ola ve ba'de vefâtihi Sadrî oğlum merhûm-1 mûmâ-ileyh Halil Reşid Efendi'nin sulbiyye kızı [75b] Hatice Hanım'a meşrûta ola ve ba'de vefâtihâ mûmâ-ileyhâ Hatice Hanım'ın evlâdının ve evlâd-ı evlâdının ve evlâd-ı evlâd-ı evlâdının batnen ba'de batnin zükûr ve inâsından eslah ve erşed ve ekberine meşrûta ola ve ba'de inkırâzi'levlâd zevcim merhûm-1 mûmâ-ileyh Murtazâ Efendi'nin evkāf-1 mezkûresine her kim mütevellî [76a] bulunur ise tevliyet-i merkûme vazîfe-i mezbûresiyle ol kimesneye meşrûtâ ola ve vakf-1 mezbûre sükkân hânkāh-1 mezbûr hasbî nâzır olalar ve şurût-1 mezkûreye ri'âyet müte'azzire olur ise vakf-1 mezbûr mutlakâ fukarâ-i müslimîne meşrûta ola ve şurût-1 merkûmenin tebdîl ve tağyîri [76b] ve taklîl ve teksîrî merraten ba'de uhrâ yedimde ola deyü ta'yîn-i şurût ve teybîn-i kuyûd edip zikr olunan bir kıt'a Mushaf-1 şerîfi ve eczâ-i şerîfeyi ve mekteb-i merkûmu ve meblağ-1 mezkûru iki ay mukaddem mütevellî-i mûmâileyhe teslîm ol dahî ahz ve emsâli gibi tasarruf eyledi dedikde gibbe'ttasdîki'ş [77a] -şer'î vâkıfe-i mûmâ-ileyhâ mevkûfû mülküne istirdâda tasaddî ve mütevellî̀-i mûmâ-ileyh dahî red ve teslîmden imtinâ' ile Mevlânâ mûmâ-ileyh huzûrunda kemâ hüve'l-mastûr fi'l-kütübi'lfıkhiyye müterâfi'ân her biri fasl ve hamse tâlibân olduklarında Mevlânâ-yı mûmâ-ileyh vakf-ı mezbûrun alâ kavl-i men yerâhu [77b] mine'l-eimmeti'l-eşrâf evvelâ sihhatine ve ba'de'l-mürâfa'a sâniyen lüzûmuna hükm-i sahîh-i şerî̂ ve kazâ-i sarîh-i mer'î eylediği mahallinde tahrîr ve ba'dehû ma'an meb'ûs emîneyn ile meclis-i şer'a gelip alâ vukû'ihî inhâ etmeğin ba'de't-tenfîz ol vechle vakf-1 mezbûr sahîh ve lâzım ve mütehattim olup nakz ve nakîzine mecâl muhâl oldu. [78a] Femen beddelehû ba'de mâ semi'ahû fe-innemâ ismuhû ale'llezîne yübeddilûnehû. İnnallâhe semî‘un alîm." Ve ecre'l-vâkıf alâ hayyi'lkayyûm cerâ zâlike ve hurrire fi'l-yevmi's-sâbi' min-Zilka'deti'ş-şerîfe lisene sitte ve seb'în ve mi'e ve elf min-hicretin men lehü'l-izz ve'ş-şeref.

Şuhûdü'l-hâl: 
108 | Nuran ÇETIN

[78b] Feyzullah Efendi ibn-i El-Hâc Hasan İmâm-1 Câmi'-i Mahmudpaşa, Dersi'âm Osman Efendi b. Ahmed, El-Hâc Abdullah b. Abdullah, Molla İbrahim b. Ali Müezzin-i Câmi'-i mezbûr, Umdetü'lmüderrisîni'l-kirâm fazîletlü Reîszâde Mustafa Âşir Efendi, Attâr İbrahim Ağa b. Halil, Mustafa Ağa b. Mehmed, Berber Mehmed Beşe b. El-Hâc Mustafa, Es-Seyyid İsmail Çelebi b. Mehmed, Mehmed b. Halil müezzin-i câmi'-i mezbûr, Mustafa Ağa b. Veli, [79a] Umdetü'l-küttâb Abdi Efendi, Na'lband Hâce Ali b. Mustafa, Umdetü'l-küttâb Rûznâmçei hümâyûn sâni sâbıkān El-Hâc Abdürrezzâk Efendi, [79b]El-emrü hasbe-mâ zükira fîhi, Ömer b. Abülkerim el-müfettiş bi-evkāfi'lharameyni'l-muhteremeyn el-mükerremeyn. Harrarahû el-fakîr-i ileyhi sübhânehû te'âlâ -gufira lehümâ-

Bismillahirrahmanirrahim

El-hamdü li-veliyyihî ve's-salâtü ve's-selâmü alâ nebiyyihi Muhammedin ve âlihî ve sahbihi ecma'în. Emmâ ba'd işbû kitâb-1 nisâbın tahrîr ve imlâ ve tastîr ve inşâsına bâ'is ve bâdî oldur ki [80a] Dârü's-sa'âdeti'ş-şerîfe ağası hazretlerinin nezâret-i aliyyelerinde olan evkāfdan sâbıkān Rûznâmçe-i evvel merhûm ve mağfûrun leh Murtazâ Efendi -tâbe serâhu- hazretlerinin Ebî Eyüb el-Ensârî -radiyallâhü te'âlâ anhü- de meşâyih-i tarîk-i Nakşibendiyye'den Kutbü'l-ârifîn Gavsü'lvâsılîn merhûm eş-Şeyh Abdullah Efendi [80b] hazretleri içün müceddeden binâ eylediği Nakşibendiyye Hânkāhı ve hayrât-1 sâireleri mühimmâtı vakfının mülhakâtından olup vâkıf-ı mûmâ-ileyh Murtazâ Efendi'nin hayâtında halîlesi sâhibetü'l-hayrât ve'l-hasenât merhûme Behrî Hâtûn bint-i Abdullah'ın zikr olunan Nakşibendiyye Hânkāhı kurbunda binâ eylediği mekteb-i şerîf mühimmâtı vakfının [81a] bervech-i meşrûta mütevellîsi olup hâlâ Galata Voyvodası olan umdetü'lemâcid ve'l-a'yân Giridî El-Hâc İbrahim Ağa b. El-Hâc Ahmed Ağa tarafından husûs-1 âti'l-beyânda vekîl olduğu Mehmed b. El-Hâc İbrahim ve Abdullah b. El-Hâc Mehmed şehâdetleriyle sâbit olan Abdi Efendi b. El-Hâc Yakûb [81b] Efendi meclis-i şer'-i şerîf-i [...] ve mahfil-i dîn-i münîf-i ezherde bi'l-vekâle ikrâr-1 sahîh-i şerîi ve i'tirâf-1 sarîh-i mer'î edip işbû yedimde olup bin yüz yetmiş altı senesi Zilka'deti'ş-şerîfesinin yedinci günü târîhiyle müverraha ve târîh-i mezkûrda Mahmudpaşa nâibi olan umdetü'l-müderrisîni'l-kirâm Yemliha Hasan Efendi'nin imzâ [82a] ve hatmini hâviye vakfiyye-i ma'mûl bahâsı mantûkunca vâkıfe-i mûmâ-ileyhâ Behrî Hâtûn ibnete Abdullah b. Abdullah hâl-i kemâl-i sıhhatinde ve târîh-i mezkûrda hâlisan li-vechillâhi te'âlâ sâlifü'z-zikr 
Nakşibendiyye Hânkāhı kurbunda binâ eylediği mekteb-i şerîfi mühimmâtı içün atyeb mâl ve enfes menâlinden ifrâz eylediği altı bin [82b] kuruşu vakf-1 sahîh-i müebbed ve habs-i sarîh-i muhalled ile vakf ve habs ve zevci mûmâ-ileyh Murtazâ Efendi'nin vakf-1 mezbûruna zamm ve ilhâk edip zikr olunan meblağ-ı mezkûr altı bin kuruş ile münâsib mahallerde akār iştirâ ve icâreteyn-i misliyyeteyn ile îcâr ve hâsıl olan icâre-i mü'eccele [83a] ve mu'accelesini mârru'z-zikr mekteb-i şerîf hademesi vezâyifine ve masârıf-ı sâire vakfına sarf olunmak üzre şart ve ta'yîn ve vakf-1 mezbûru mütevellîsi müvekkilim mûmâ-ileyh Girîdî İbrahim Ağa'ya teslîm ile tescîl-i şer'î eylediğinden sonra vâkıfe-i mûmâ-ileyhâ Behrî Hâtûn fevt olmakla müvekkilim [83b]mütevellî mûmâ-ileyh Giridî İbrahim Ağa dahî işbû yedimde olan hücec-i şer'iyye mantûklarınca ber-mûceb-i şart-1 vâkıf makbûzu olan nukûd-ı mezkûre altı bin kuruşdan beş bin beş yüz kuruş ile vakf-1 mezbûre akār olmak üzre bi't-tevliye iştirâ ve teslîm etmekle ol vechle vakf-1 mezbûr musakkafâtından olan mahmiyye-i [84a] İstanbul'da Molla Gürânî Mahallesi'nde vâki' bir tarafdan Prinççi kızı menzilî ve bir tarafan mehter hamâmı ve bir tarafan Fâtıma Hâtûn'un mülk menzili ve bir tarafan tarîk-i âm ile mahdûd tûlen ve arzan be-hesâb-1 terbî'î bin iki yüz yetmiş altı buçuk zirâ' arsa üzerinde mebnî tabaka-i ulyâda iki bâb oda ve iki sofa ve dehlîz ve süflâda [84b] üç bâb oda ve iki sofa ve bir dehlîz ve bir kârgîr hammâm ve câmekān odası ve iki matbah ve bir bi'r-i mâ ve bir kenîf ve bir mikdâr bahçe ve müştemilât-ı sâireyi hâvî cevânib-i erba'ası taş duvarı muhtevî yevmî iki akçe icâre-i mü'ecceleyi mütehammil bir bâb menzil ve yine mahmiye-i İstanbul'da Sancakdâr Hayreddin Mahallesi'nde vâki' bir tarafdan Osman Çelebi [85a] veresesi menzili ve bir tarafan Yorgancı Mustafa Çelebi menzili ve bir tarafan Mehmed Çelebi veresesi menzili ve bir tarafan tarîk-i âm ile mahdûd tûlen ve arzan be-hesâb-1 terbî̀̂̂ dört yüz altmış iki zirâ' arsa üzerinde mebnî hâriciyyede tabaka-i ulyâda bir bâb oda ve bir sofa ve dehlîz ve bir köşk ve tabaka-i vustâda iki bâb oda [85b] ve dehlîz ve kenîf ve süflâda bir ahır ve kenîf ve dâhiliyede tabaka-i ulyâda bir bâb oda ve kiler ve tabaka-i vüstâda iki oda ve abdesthâne ve kenîf ve süflâda bir matbah ve bir mağsel ve mahzen ve bir bi'r-i mâ ve bahçe ve müştemilât-1 sâire-i mâ'lûmeyi hâvî yevmî iki akçe icâre-i mü'ecceleyi mütehammil bir bâb menzil ve yine mahmiye-i İstanbul'da [86a] Sultanahmed kurbunda Nahlbend Mahallesi'nde vâki've bir tarafan ba'zan Baba Ali ve ba'zan İbrahim Ağa mülkleri ve bir tarafan Abdullah Ağa ve ba'zan Mehmed 


\section{0 | Nuran ÇETIN}

Ağa mülkleri ve bir tarafan Hatice Hanım ve ba'zan Abdullah Ağa mülkleri ve bir tarafan tarîk-i hâs ile mahdûd tûlen ve arzan be-hesâb-1 terbî'î iki yüz zirâ' arsa üzerinde mebnî [86b] dâhiliyede tabaka-i ulyâda bir oda ve bir sofa ve dehlîz ve abdesthâne ve tabaka-i vustâda bir oda ve bir kiler ve süflâda bir matbah ve mahtab ve mağsel ve kenîf ve bir mikdâr havlu ve hâriciyyede fevkānî bir oda ve tahtında bir kenîf ve kömürlük ve orta kapı ve müştemilât-ı sâire-i ma'lûmeyi hâvî yevmî bir akçe icâre-i [87a] mü'ecceleyi mütehammil bir bâb menzil ve yine mahmiye-i merkûmede Kumkapı kurbunda Cerrâh İshâk Mahallesi'nde vâki' bir tarafdan Arabacı Abdî menzili ve bir tarafan Abdullah menzili ve iki tarafdan tarîk-i hâs ile mahdûd ve tûlen ve arzan be-hesâbi't-terbî'î yüz kırk beş zirâ' arsa üzerinde mebnî fevkānî iki bâb oda ve bir sofa ve dehlîz [87b] ve vustâda bir oda ve bir matbah odası ve kiler ve kenîf ve süflâda bir mahtab ve kömürlük ve bi'r-i mâ ve havluyu ve müştemilât-1 sâireyi ma'lûmeyi hâvî yevmî bir akçe icâre-i mü'ecceleyi mütehammil bir bâb menzil ve yine mahrûsa-i Galata'ya muzâfe Ortaköy'de vâki' bir tarafdan Aranici oğlu Hacdor zimmî menzili ve bir tarafan Sara Nasrâniyye [88a] menzili ve bir tarafan ba'zan Hamparsun ve ba'zan [...] oğlu zimmî menzilleri ve bir tarafan tarîk-i âm ile mahdûd tûlen ve arzan be-hesâbi't-terbî'î yalnız üç yüz yirmi zirâ' arsa üzerinde mebnî a'lâ-yı ulyâda bir tahte's-semâ' ve ulyâda bir oda ve bir sofa ve bir matbah odası ve dehlîz ve kenîf ve vustâda bir oda ve bir sofa ve bir [88b] matbah odası ve dehlîz ve kenîf ve süflâda bir oda ve bir tahta mahzen ve matbah ve kömürlük ve iki bi'r-i mâ ve eşcâr-1 müsmire ve gayr-1 müsmireli bahçe ve müştemilât-1 sâ'ireyi hâvî yevmî iki akçe icârei mü'ecceleyi mütehammil bir bâb menzil ve yine mahmiye-i İstanbul'da Kocamustafapaşa Câmi'-i şerîfi kurbunda Canbâziyye Mahallesi'nde vâki' bir tarafdan Hüseyin [89a] Odabaşı menzili ve bir tarafan Hallâc İbrahim Beşe menzili ve bir tarafan Hammâmî Bekir Efendi menzili ve bir tarafan tarîk-i âm ile mahdûd tûlen ve arzan be-hesâbı't-terbî'î yalnız beş yüz altmış zirâ' arsa üzerinde mebnî hâriciyyede fevkānî iki bâb oda ve bir sofa ve abdesthâne [89b] ve dehlîz ve tahtânî bir sâğîr oda ve ahır ve kenîf ve taş musluk ve bir mikdâr havlu ve dâhiliyyede ulyâda iki bâb oda ve bir sofa ve tahta pûş ve vüstâda bir sağîr oda ve bir sofa ve hammâm ve câmekān odası ve abdesthâne ve süflâda matbah ve kenîf ve mezbûr Hüseyin Odabaşı ile müşterek su kuyusu ve bahçeyi ve [90a] müştemilât-1 sâireyi hâvî yevmî iki akçe icâre-i mü'ecceleyi mütehammil bir bâb menzil ve Medîne-i hazret-i Eyyüb el-Ensârî aleyhi rahmetü'l- 
Bâri'de İdris Köşkü nâm mahalde Zeyneb Hâtûn Mahallesi'nde vâki' bir tarafdan Nakşibendî şeyhine meşrût menzil ve bir tarafdan Kalaycı Bahçesi ve bir tarafdan Hatice Hâtûn menzilî[90b] ve bir tarafan tarîk-i âm ile mahdûd tûlen ve arzan be-hesâbi't-terbî‘̂i sekiz yüz elli zirâ' arsa üzerinde mebnî fevkānî iki bâb oda ve bir sofa ve dehlîz ve tahtânî iki oda ve bir sofa ve dehlîz ve matbah ve bahçe ve havuz ve tahte's-semâ' ve iki sokak kapısı müştemil yevmî bir akçe icâre-i mü'ecceleyi mütehammil bir bâb menzil ve yine mahrûsa-i [91a] Galata'ya muzâfe kasaba-i Beşiktaş'a tâbi' Ortaköy'de vâki' bir tarafdan Yakomî zimmî menzili ve bir tarafan ba'zan Dülger Evnes ve ba'zan Sokyas zimmîler menzilleri ve iki tarafdan tarîk-i âm ile mahdûd tûlen ve arzan behesâbı't-terbî'î yalnız üç yüz on zirâ' üzerinde mebnî fevkānî bir bâb oda ve bir sofa ve tahtânî [91b] bir matbah ve mahtab ve bi'r-i mâ ve kenîf ve eşcâr-1 müsmire ve gayr-1 müsmireli bahçe ve müştemilât-1 sâire-i ma'lumeyi hâvî yevmî iki akçe icâre-i mü'ecceleyi mütehammil bir bâb menzil ve yine Medîne-i Hazret-i Ebî Eyüb el-Ensârî aleyhi rahmeti'lBârî'de İdris Köşkü nâm mahalde Zeyneb Hâtûn Mahallesi'nde vâki' bir tarafdan tekke-i mezbûrede İmâm [92a] olanlara meşrût olan menzil ve bir tarafdanBaş muhasebe hulefâsından El-Hâfız İsmail Efendi Vakfı musakkafâtından Nakşibendî şeyhi Abdullah Efendi tasarrufunda olan menzil ve bir tarafdan Kassâb Yazıcısı Molla İbrahim menzili ve bir tarafdan tarîk-i âm ile mahdûd tûlen ve arzan be-hesâbı't-terbî'î yalnız iki yüz yetmiş [92b]zirâ' arsa üzerinde mebnî buyût-1 adîde ve müştemilât-1 ma'lûmeyi muhtevî yevmî bir akçe icâre-i mü'ecceleyi mütehammil bir bâb menzil ve yine Medine-i merkûme mahallâtından Aşcıbaşı Mahallesi'nde vâki' bir tarafdan Çarhcı Ömer Ağa menzilî ve bir tarafdan Odabaşı veresesi menzilleri ve bir tarafdan Sâlih Ağa menzili ve bir tarafdan tarîk-i âm ile mahdûd [93a] tûlen ve arzan be-hesâbı't-terbî'î yedi yüz zirâ' arsa üzerinde mebnî fevkānî ve tahtânî üç bab oda ve dehlîz ve matbah ve iki bi'r-i mâ ve kenîf ve bahçe ve müştemilât-1 sâire-i ma'lûmeyi hâvî yevmî bir akçe icâre-i mü'ecceleyi mütehammil bir bâb menzil ve yine Medîne-i mezbûre mahallâtından Câmi'-i Kebîr Mahallesi'nde vâki' Külhan Sûk'unda vâki' bir tarafdan [93b] Emine Hâtûn menzili ve bir tarafdan Odabaşı veresesi menzili ve iki tarafdan tarîk-i hâs ile mahdûd tûlen ve arzan be-hesâbi't-terbî'î yalnız seksen zirâ' arsa üzerinde mebnî fevkānî ve tahtânî iki bâb oda ve dehlîz ve kenîf ve kanevât-1 memlûke ile nısf çuvaldız mâ-i lezîz-i cârî ve su hazînesi ve müştemilât-1 sâire-i ma'lûmeyi hâvî [94a] yevmî bir akçe 


\section{2 | Nuran ÇETIN}

icâre-i mü'ecceleyi mütehammil bir bâb menzil ve yine Medîne-i mezbûre mahallâtından Otakçılar Mahallesi'nde vâki' bir tarafdan mahalle imâmına meşrût olan vakf menzil ve bir tarafdan Âişe Hâtûn menzili ve bir tarafdan El-Hâfız İbrahim Efendi menzili ve bir tarafdan tarîk-i âm ile mahdûd tûlen ve arzan be-hesâbı't-terbî'̂̂ [94b] yalnız dört yüz elli zirâ' arsa üzerine mebnî fevkānî iki bâb oda ve dehlîz ve tahtânî iki bâb oda ve müşterek bi'r-i mâ ve kenîf ve bahçe ve müştemilât-1 sâirei ma'lûmeyi muhtevî yevmî bir akçe icâre-i mü'ecceleyi mütehammil bir bâb menzil ve yine Medîne-i merkûmede Otakçılar Mahallesi'nde vâki' bir tarafdan yine vakf-1 mezbûrdan Taşcı [95a] Mehmed Ağa tasarrufunda olan menzil ve bir tarafdan yine vakf-1 mezbûrdan Nakkâş İbrahim Çelebi tasarrufunda olan menzil ve bir tarafdan imâma meşrûtası olan menzil ve bir tarafdan tarîk-i âm ile mahdûd tûlen ve arzan be-hesâbı't-terbî'̂̂ yalnız yemiş zirâ' arsa üzerinde mebnî fevkānî bir bâb oda ve bir sofa ve tahtında matbah ve kiler ve kenîf ve havlu [95b]ve müştemilât-1 sâire-i ma'lûmeyi hâvî yevmî nısf akçe icâre-i mü'ecceleyi mütehammil bir bâb menzil ve yine Medîne-i merkûmede Otakçılar Mahallesi'nde vâki' bir tarafdan vakf-1 mezbûrdan İbrahim Efendi tasarrufunda olan menzil ve bir tarafdan imâma meşrût olan menzil ve iki tarafdan tarîk-i âm ile mahdûd tûlen ve arzan be-hesâbı'tterbî'î yalnız [96a] üç yüz otuz zirâ' arsa üzeride mebnî fevkānî iki bâb oda ve bir sofa ve dehlîz ve tahtında bir matbah ve bahçe ve müştemilât-1 sâire-i ma'lûmeyi hâvî yevmî bir akçe icâre-i mü'ecceleyi mütehammil bir bâb menzil ve yine mahmiye-i İslambol'da İskender Paşa Mahallesi'nde vâki' bir tarafdan Yorğanî Mustafa Ağa menzili ve bir tarafdan El-Hâfız Mehmed Efendi menzili [96b] ve iki tarafdan tarîk-i hâs ile mahdûd tûlen ve arzan be-hesâbı't-terbî'î yalnız seksen zira' arsa üzerinde mebnî fevkānî iki bâb oda ve dehlîz ve tahtânî bir matbah ve abdesthâne ve kenîf ve havlu ve müştemilât-1 sâire-i ma'lûmeyi hâvî yevmî bir akçe icâre-i mü'ecceleyi mütehammil bir bâb menzil ve yine mahmiye-i mezkûrede Ayvansarây Kapısı dâhilinde Toklu Dede Mahallesi'nde [97a] vâki' bir tarafdan Zeyneb Hâtûn menzili ve bir tarafdan Emîr Buhârî Hazretleri Tekyesi ve bir tarafdan El-Hâc Osman veresesi menzilleri ve bir tarafdan tarîk-i âm ile mahdûd tûlen ve arzan be-hesâbı't-terbî'î yalnız yüz altmış beş zirâ' arsa üzerinde mebnî ulyâda bir oda ve dîvânhâne ve vustâda bir oda ve dehlîz ve abdesthâne [97b] ve kenîf ve süflâda bir matbah ve bi'r-i mâ ve bahçe ve müştemilât-1 sâire-i ma'lûmeyi hâvî yevmî bir akçe icâre-i mü'ecceleyi mütehammil 
bir bâb menzil ve yine mahmiye-i merkûmede Edirnekapısı kurbunda El-Hâc Muhyiddin Mahallesi'nde vâki' iki tarafdan Çadırcı Hasan Ağa menzili ve iki tarafdan tarîk-i âm ile mahdûd tûlen ve arzan be-hesâbi'tterbî'î [98a] yalnız üç yüz elli zirâ‘ arsa üzerinde mebnî hâriciyyesinde fevkānî iki bâb oda ve bir sofa ve vustâda iki bâb oda ve tahtında ahır ve kenîf ve dâhiliyyesinde fevkānî iki bâb oda ve bir sofa ve dehlîz ve tahtânî bir bâb oda ve bir kiler ve matbah ve mağsel ve kenîf ve bir mikdâr bahçe ve orta kapı ve cevânib-i erba'ası taş duvar [98b] ve müştemilât-ı sâire-yi ma'lûmeyi hâvî yevmî iki akçe icâre-i mü'ecceleye mütehammil bir bâb menzil ve yine mahrûsa-i Galata'ya muzâfe kasaba-i Kasımpaşa'da Câmi'-i Kebîr Mahallesi'nde vâki' bir tarafdan Derviş Mûsâ menzili ve bir tarafdan Kapıcıoğlu menzili ve bir tarafdan Kayyımzâde Ali Çelebi menzili ve bir tarafdan tarîk-i âm ile mahdûd tûlen ve arzan be-hesâbi't-terbî'î yalnız [99a] üç yüz zirâ' arsa üzerinde mebnî fevkānî üç bâb oda ve bir sofa ve dehlîz ve matbah ve tahtânî bir bâb oda ve mahtab ve bi'r-i mâ ve kenîf ve bir mikdâr bahçe ve müştemilât-1 sâire-i ma'lûmeyi hâvî yevmî bir akçe icâre-i méecceleyi mütehammil bir bâb menzil ve yine mahrûsa-i Galata'ya muzâfe kasaba-i Fındıklı'da Avni Efendi Mahallesi'nde vâki' bir tarafdan [99b] Rukiye Hâtûn menzili ve bir tarafan Mehmed veresesi menzileri ve bir tarafdan Süleyman Efendi menzili ve bir tarafdan tarîk-i âm ile mahdûd tûlen ve arzan be-hesâbı't-terbî'î yalnız seksen zirâ' arsa üzerinde mebnî fevkānî bir bâb oda ve dehlîz ve tahtânî bir bâb oda ve mağsel ve kenîf ve mezbûre Rukiyye'nin menzili derûnunda kömürlüğü havâsında vâki' bir tahte-pûş ve bir [100a] câmeşûy ocağ1 ve müştemilât-1 sâire-i ma'lûmeyi hâvî yevmî nısf akçe icâre-i mü'ecceleyi mütehammil bir bâb menzil ve yine Galata-i mahrûsaya muzâfe kasaba-i Kasımpaşa'da El-Hâc Hasan Mahallesi'nde vâki' bir tarafdan Balta oğlu menzili ve bir tarafdan tarîk-i hâs ve bir tarafdan ba'zan Âişe Hâtûn ve ba'zan dahî diğer Âişe Hâtûn menzilleri [100b] ve bir tarafdan tarîk-i âm ile mahdûd ve tûlen ve arzan be-hesâbı't-terbî'î yalnız iki yüz kırk zirâ' arsa üzerinde mebnî dâhiliyede fevkānî bir bâb oda ve bir sofa ve dehlîz ve tahtânî bir matbah ve kârgîr hammâm ve müşterek bi'r-i mâ ve kenîf ve bir mikdâr havlu ve bahçe ve hâriciyyede fevkānî iki bâb oda ve köşk ve dehlîz ve kenîf ve müştemilât-1 sâire-i ma'lûmeyi [101a] hâvî yevmî bir akçe icâre-i mü'ecceleyi mütehammil bir bâb menzil ve yine mahmiye-i İstanbul'da Sancakdâr Hayreddin Mahallesi'nde vâki' bir tarafdan Daşko Nasraniye menzili ve bir tarafdan ba'zan Mina Nasraniye ve ba'zan Evanes 


\section{4 | Nuran ÇETIN}

zimmîveresesi menzilleri ve bir tarafdan Babuşçu Nikogos zimmî menzili ve bir tarafdan tarîk-i âm ile mahdûd tûlen [101b] ve arzan behesâbı't-terbî̀î yalnız yüz on beş zirâ' arsa üzerinde mebnî tabaka-i ulyâda bir bâb oda ve bir matbah ve dehlîz ve tahte's-semâ' ve vustâda bir bâb oda ve matbah ve dehlîz ve süflâda bir bâb oda ve bir matbah ve bodrum ve bir mikdâr havlu ve müştemilât-1 sâire-i ma'lûmeyi hâvî yevmî bir akçe icâre-i mü'ecceleyi [102a] mütahammil bir bâb menzil ve yine mahrûsa-i Galata'da vâki' Câmi'-i Kebîr Mahallesi'nde vâki' bir tarafdan Yeniçeri Efendisi Mustafa Efendi menzili ve bir tarafdan cidâr-1 hısn ve bir tarafdan Meryem bint-i Mı̆̆ırdıç Nasrâniyye menzili ve bir tarafdan tarîk-i âm ile mahdûd tûlen ve arzan be-hesâbı't-terbî'î yalnız üç yüz on zirâ' arsa üzerinde mebnî [102b] fevkānî ve tahtânî beş oda ve bir mahzen ve matbah ve kenîf ve bahçe ve müşterek sarnıç ve bir sokak kapısı ve müştemilât-1 sâire-i ma'lûmeyi hâvî yevmî iki akçe icâre-i mü'ecceleyi mütehammil bir bâb menzil ve yine mahmiye-i İstanbul'da Langa-i Kebîr kurbunda Kâtib Kâsım Mahallesi'nde vâki' bir tarafdan Parsmi Nasrâniyye ve zevci Îsâî [103a] zimmî menzilleri ve bir tarafdan Kapamacı Aleksan zimmî menzilî ve bir tarafdan Gül Nasrâniye menzili ve bir tarafdan tarîk-i âm ile mahdûd tûlen ve arzan be-hesâbi't-terbî'̂̂ yalnız yüz elli iki zirâ' üzerinde mebnî fevkānî bir oda ve bir sofa ve dehlîz ve tahte's-semâ' ve cihânnümâ ve tahtânî bir oda ve iki matbah ve bahçe ve zîr-i zemînde bir kârgîr mahzen [103b] ve ayazma ve bi'r-i mâ ve kenîf ve müştemilât-1 sâire-i ma'lûmeyi hâvî yevmî iki akçe icâre-i mü'ecceleyi mütehammil bir bâb menzil ki cem’an yevmî otuz akçe mü'eccele mütehammil min-haysi'l-mecmû' yimi üç bâb menâzili bermûceb-i şart-1 vâkıfa vakf-1 mezbûre zam ve ilhâk ve ber-vech-i muharrer icâre-i mü'eccele-i mu'ayyene mezkûreleri ve mu'accele misilleri ile tâlibîne bi't-tevliye [104a] îcâr edip menâzil-i mezkûre vakf-1 mezbûr musakkafâtından olmağın cânib-i vakfından zabt ve tasarrufları içün kıbel-i şer'-i enverden yedime vesîka verilmesi matlûbumdur deyü ibrâz eylediği vakfiyye-i mezkûre ve hucec-i şer'iyye-i müte'addideye nazar olundukda mazmûnları mütevellî vekîli mûmâ-ileyh Abdi Efendi'nin takrîr-i meşrûhuna [104b]mutâbık olduğundan gayrı hâlâ mütevellî vekîli mûmâ-ileyhin takrîr-i meşrûhu üzere olduğunu zeyl-i vesîkada muharrerü'l-esâmî bi-garaz müslimîn alâ tarîki'ş-şehâde haber vermeleriyle li-ecli'l-istihkâm işbû vesîka-i [...] mâ hüve'l-vâki' bi't-taleb ketb ve imlâ olundu. Cerâ zâlike hurrire fî gurret Cumâde'l-âhire [105a] li-sene tis'a ve seb'în ve mi'e ve elf. 
Şuhûdü'l-hâl:

Fahrü'l-müderrisîni'l-kirâm Hamdullâh Beyefendi b. el-merhûm Ebubekir Paşa, Umdetü'l-emâcid Ataullah Efendi Bey b. el-merhûm Ebûbekir Paşa, Umdetü'l-emâcid ve'l-ekârim Abdürrezzak Efendi b. Mustafa Efendi mektûbî-i hazreti sadr-1 âli, Umdetü'l-emâcid ve'l-a'yân Haseki Mustafa Ağa Matbah-ı âmire emîn-i sâbıkān, Umdetü'l-emâcid ve'l-ekârim Âşir Mustafa Efendi Reîszâde, [105b] Hâfız İbrahim Efendi Hâce-i Mekteb-i şerîf-i vakf-1 mezbûr, El-Hâc Mehmed Efendi Müezzin-i Mahalle, Süleyman Efendi Kâtib-i Simkeşhâne, El-Hâc Yûsuf Efendi Kâtib-i Simkeşhâne, Hâfız Abdülkadir Efendi b. imâm-1 mahalle, El-Hâc Hasan Ağa Veznedâr-1 Simkeşhâne, El-Hâc Sâlih Ağa, Hâfız Süleyman Efendi b. Mustafa, Abdurrahman Çelebi, İbrahim Efendi, Mehmed Beşe,El-Hâc İbrahim Ağa ve gayrihim mine'l-huzzâr.

\section{EK 2}

\section{Murtazâ Efendi Vakfiyesi'nin Ön Kısmı}

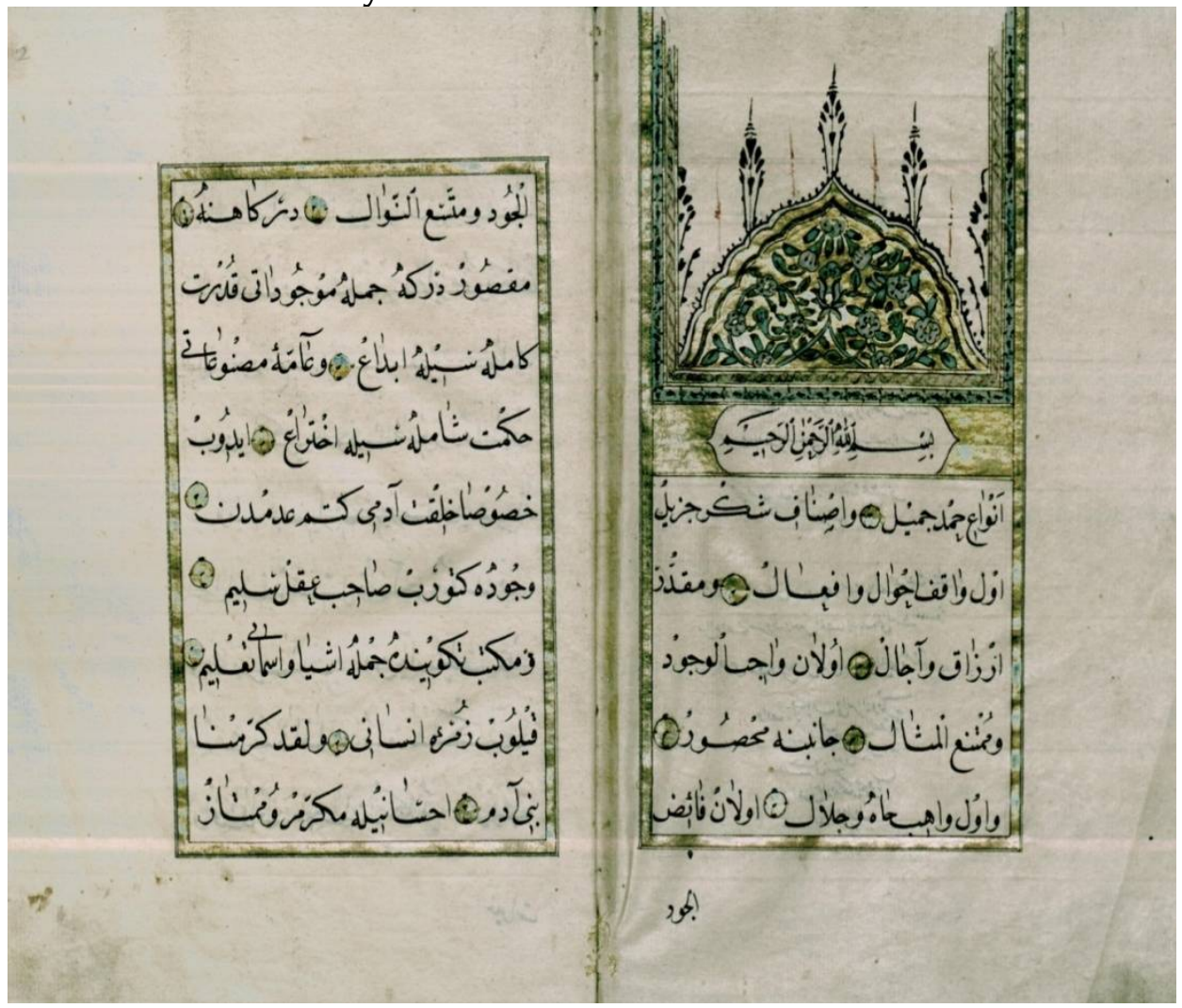


116 | Nuran ÇETIN

\section{Kaynakça}

Berki, Ali Himmet, Vakfa Dair Yazllan Eserlerde Vakfiye ve Benzeri Vesikalarda Geçen Istılah ve Tâbirler, VGM Yay., Ankara, ty.

Devellioğlu, Ferit, Osmanlıca-Türkçe Ansiklopedik Lugat, Aydın Yay., Ankara, 2012.

İstanbul Müftülüğü Meşihat Arşivi, el-Hâc Murtazâa Efendi Vakfiyesi, nr., 1702.

Kazıcı, Ziya, Osmanlı Vakıf Medeniyeti, Bilge Yay., İstanbul, 2003.

Pakalın, M. Zeki, Osmanlı Tarih Deyimleri ve Terimleri Sözlüğ̈̈, Milli Ĕgitim Basımevi, İstanbul, 1993.

Sertoğlu, Mithat, Osmanlı Tarih Lügatı, Enderun Kitabevi, İstanbul, 1986.

Süreyyâ, Mehmed, Sicill-i Osmanî, Matbaa-i Âmire, İstanbul,1308.

Şem'dânî-Zâde Fındıklılı Süleyman Efendi. Mü'ri'it-Tevârih, (nşr. Münir Aktepe), İstanbul Üniversitesi Edebiyat Fakültesi, İstanbul, 1976.

Unat, Faik Reşit, Hicrî Tarihleri Milâdî Tarihe Çevirme Kılavuzu, Türk Tarih Kurumu Basımevi, Ankara,1974.

Vassâf, Hüseyin, Sefine-i Evliyâa-yı Ebrâr Şerh-i Esmâr-ı Esrâr, Süleymaniye Kütüphanesi Yazma Bağışlar, nr. 2306. 